\title{
Structure in Distance Learning: A Systematic Literature Review
}

\author{
Bülent Kandemir* \\ Computer Technologies, Ordu University, Ordu, Turkey \\ ORCID: 0000-0002-2852-547X
}

\author{
Ebru Kılıç Çakmak \\ Department of Computer Education and Instructional Technologies Education, Gazi \\ University, Ankara, Turkey \\ ORCID: 0000-0002-3459-6290
}

Article history

Received:

01.03.2021

\section{Received in revised form:} 05.04.2021

\section{Accepted:}

14.04.2021

Key words:

Distance education;

Transactional distance;

Course structure;

Flexibility-rigidity;

Curriculum;

Instructions;

Technology;

Evaluation.
The research aims to determine the elements under the structural component in distance learning environments. The research was conducted as a systematic literature review. The research was conducted on a total of 54 studies. The studies were accessed through the electronic databases accessible at Gazi University. A PRISMA flow chart was used to select the studies. The classification of the studies into categories and codes was done using content analysis, in terms of the structural component. A total of 78 codes were found in 5 categories under which 5409 codings were made. It was found that under the structural component, the Technology category was the most frequently used. This category is followed by flexibility-rigidity, assessment, guidance and curriculum. The most frequently used code in the studies is individual feedback, which falls under the flexibility-rigidity category. As a result of the study, some suggestions were made for designers of distance education media. They should pay maximum attention to the flexibilityrigidity category to support students' sense of belonging. It is recommended to use different (textual, audio/video) feedback methods in the learning environment. They are expected to pay more attention to the Curriculum category to support learner success. The roles of teachers and learners should be clearly defined. Technology should be planned to support all processes such as interaction, access to content, communication, sharing, collaboration, and evaluation that may be experienced in the learning environment. Formative evaluation should be considered important and more than one method of performance assessment should be used. Since technological platforms are the basic elements of communication, they should be used extensively in learning environments.

\section{Introduction}

It is noted that the number of students in distance education has been steadily increasing in recent years (Seaman, Allen, \& Seaman, 2018). It is noted that the rate of higher education students benefiting from distance education courses was $25.9 \%, 27.1 \%, 28.3 \%$ and

\footnotetext{
*Correspondency: bulentkandemir@ odu.edu.tr
} 
$29.7 \%$ in 2012, 2013, 2014 and 2015 respectively. This situation shows that the number of students increased by $17.2 \%$ from 2012 to 2016. However, despite the innovative developments in distance education in recent years, typical problems remain (Weidlich \& Bastiaens, 2018). Interaction plays an important role amongst all these (Aghaee et al., 2016; Anderson, 2003; Berge et al., 2002; Dede, 1996; Dockter, 2016; Falowo, 2007; Galusha, 1998; Kyei-Blankson et al., 2019; Xiao, 2017; Yazıc1 et al., 2001).

Since learning is a socially mediated activity, interaction is necessary for education (Dewey, 1923; Vygotsky, 1980). The first goal in education is interaction (Berge, 2002). In this context, interaction is crucial in the distance education process, as in all educational settings (Alhih et al., 2017; Garrison, 1991; Garrison, 2000; Holmberg \& Ortner, 1991; Moore \& Kearsley, 2011; Olpak \& Çakmak, 2014).

According to Moore (1989), one of the pioneers of distance education, there are three types of interactions. These are learner-content, learner-teacher, and learner-learner interactions (Moore, 1989). Moore argues that when these three types of interactions are positively established, it results in meaningful learning for the individual. Moore later developed the transactional distance theory along with the interaction types, using Wedemeyer's independent work and Holmberg's theories of communication and interaction as a bridge (Moore, 1993). The concept of distance in the theory is used to express communication and transactional distance between participants rather than physical distance. Distance is defined as a twodimensional framework consisting of dialog and structure (Gunawardena \& McIsaac, 2013). Dialog is expressed as the process of interaction between learners' communication with each other or with the instructor (Moore \& Kearsley, 2011). Structure, on the other hand, is a measure of the ability of educational programs to meet the needs of learners and the presentation of content (Saba, 2016). With this characteristic, structure has a crucial role in the interaction between learners and content.

In examining the studies on distance education, many studies have been conducted on learnerteacher and learner-learner interaction. However, it is noted that the lack of studies on learnercontent interaction creates a serious contrast (Xiao, 2017). Zimmerman (2012) points out the important role of learner-content interaction and mentions that very little work has been done in this area. Various researchers such as Moore (1989), Sims (1997), Rhode (2009), Friesen and Kuskis (2013), Goh et al. (2019) emphasize the need to study learner-content interaction. The learner-content interaction is expected to ensure that the learner makes the best use of the system independently of the instructor and achieves the set goals without live instruction. Here, the structural elements that make up the content and how they are organized (low, medium, high) play a key role in learner-content interaction.

In order for learner-content interaction to occur at the desired level, the non-individual factor of content, indirectly the design of the course structure, is of great importance. Although many studies have been conducted on course structure, the structural components have been grouped by Moore (1993) under the titles of flexibility and rigidity, course organization, curriculum, policies, the technology used, and evaluation. However, it is worth noting that course organization and its components that belong to these elements are mostly distributed among other elements. According to Moore and Kearsley (2011), course organization refers to the appropriate combination of content topics, objectives, instructions, policies, and the evaluation process. Based on this transitive property of the course organization component, the structural components; the degree of flexibility and rigidity of the curriculum, instruction, technology, and assessment can be classified under the main headings. The degree of 
flexibility and rigidity is a measure of the structure's ability to meet the individual needs of each learner (Lemak et al., 2005), it is adaptable (Jung, 2001). It is the component in which the syllabus, course objectives, instructional strategy, and expectations are clearly stated. Instructions are structural elements that provide students with explanations of activities (Desharnais \& Limson, 2007). Technology is the interface through which the student communicates with the course content (Vonderwell \& Zachariah, 2005). It reflects the tools used in the course such as text, graphics, audio, video, email, routing, and messaging (Grigorovici et al., 2003). Evaluation refers to the measurement of students in distance education, using assessment methods appropriate for the target audience (Blass \& Davis, 2003).

When examining current studies, one finds that designers and developers do not pay enough attention to the structured dimension. It is noteworthy that there are also different opinions regarding its components. Moreover, it is noticeable that most studies focus more on components such as flexibility-rigidity and evaluation than on other components. This situation poses a great task for designers and developers in deciding the structure and components of the new study to be conducted. Studies show that not only the learner-content but also the structure and its components play an important role in increasing the interaction between learner-learner and learner-teacher (Pawan, Paulus, Yalcin and Chang, 2003; Thorpe, 2014). In this context, the studies on the structure dimension in online learning environments will be mainly examined. The examination of the structure dimension and the determination of its components will guide the designers and developers who will work in the field of distance education. In addition, the examination of the studies conducted in this context will help to uncover the current structural components. The research sought to answer the following questions.

(1) How is the flexibility-rigidity category of the structural dimension in the studies?

(2) How is the curriculum category of the structural dimension in the studies?

(3) How is the instructions category of the structural dimension in the studies?

(4) How is the technology category of the structural dimension in the studies?

(5) How is the evaluation category of the structural dimension in the studies?

(6) Which codes are the most studied codes and categories in the studies?

\section{Method}

\section{Research Design}

The research was conducted through a systematic literature review. A systematic literature review is the use of systematic methods to identify relevant research, selection, critical appraisal, data collection and data analysis (Moher et al., 2009). The general process steps for literature review are shown in Figure 1. These process steps were carried out following the PRISMA (Preferred Reporting Items for Systematic reviews and MetaAnalyses) flowchart structure (Moher et al., 2010). 

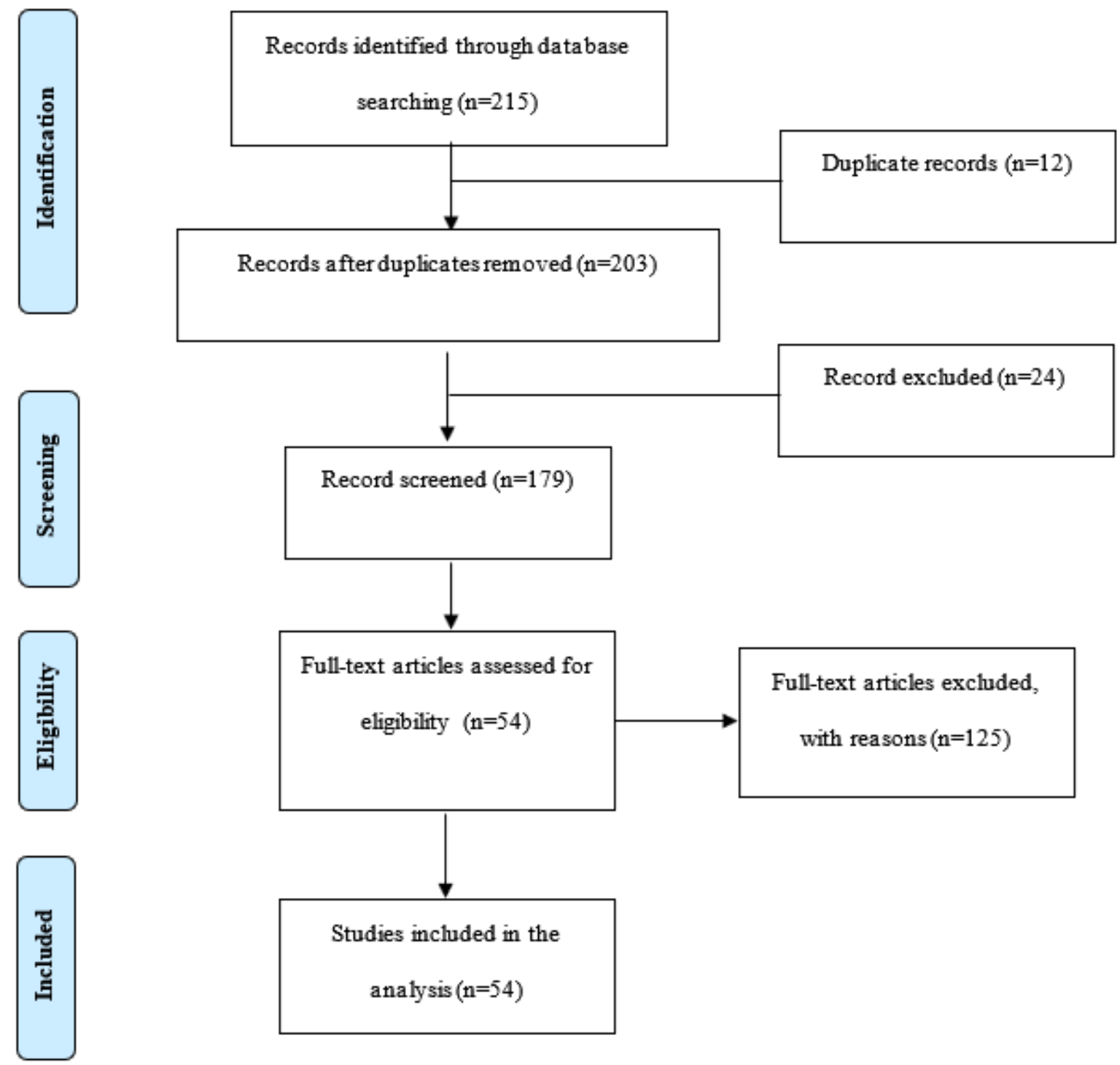

Figure 1. PRISMA Flow Chart for Sourcing

The studies included in the study were analysed by classifying them into categories and codes using the content analysis method. Organising, classifying, comparing the texts and extracting the results from the studies was done using the content analysis method (Cohen et al., 2007). The entire research process was carried out in Figure 2. 


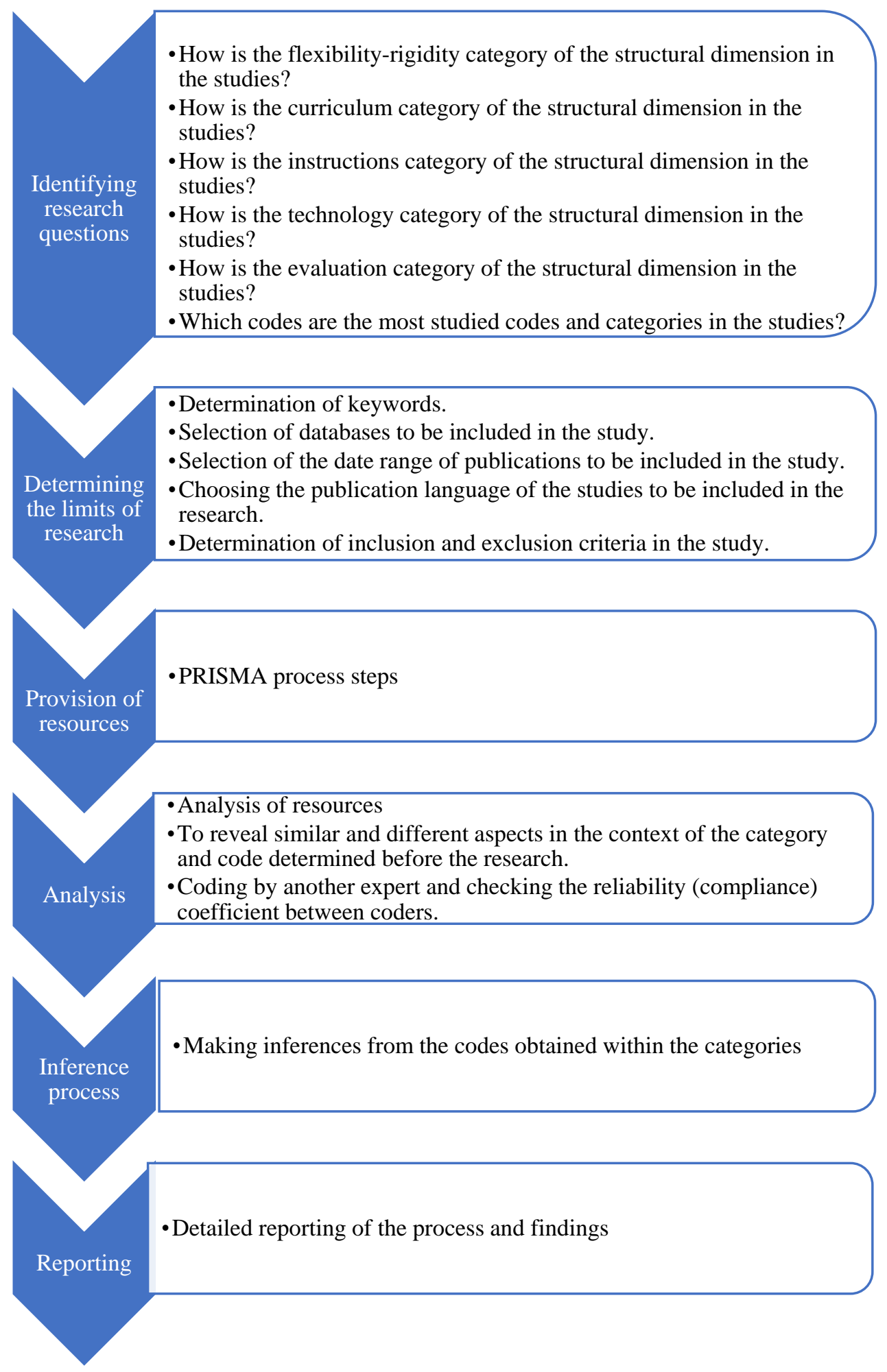

Figure 2. Research process

\section{Data Collection and Inclusion Criteria}

In the literature, course structure is seen in distance education, which is expressed by the terms online course structure, distance course structure, and online structure. Moreover, in transactional distance theory, there are studies that include structure parameters in distance 
education. For this reason, the terms "online course structure", "distance course structure", "online structure", "transactional distance", and "distance education and course structure" were used as keywords in the scanning process. The studies to be included in the study were retrieved from the electronic library Gazi University Academic Search Ultimate, EBSCOhost, and the databases ERIC. The screening was conducted during two years i.e., between the years 2018-2020. The number of publications of similar studies was analyzed and the criterion of timeliness were considered in the selection of the year range. Boelens et al. (2017) examined 20 studies in their research in which they investigated the 4 main difficulties of blended learning design, Özbay and Sarıca (2019) examined the trends of studies conducted in flipped classroom in 64 studies, and Muljana and Luo (2019) examined 40 studies in their research in which they found the factors affecting the completion rate in online learning. For this reason, 2020 was scanned first and 2019 and 2018 were included in the study. Also, it can be seen that the studies increased between the years 2010-2020 especially in the last 3 years. English was chosen as the publication language. During scanning, the studies listed in the previous keywords were excluded to avoid duplicate publication. Even if there is a study with the same name which was both an article and a dissertation, only the studies published as research articles were included in the search to avoid repeating the data. Studies which are not accessible, whose full text is not available and written in different languages were not included in the study. Accordingly, a total of 54 studies were searched including 45 articles, 6 dissertations, 2 conferences and 1 journal. The keywords included in the study, the number of accesses and the relevant publications are listed in Table 1.

Table 1. Keywords included in the research and the number of publications found.

\begin{tabular}{|c|c|c|c|c|}
\hline Keyword Used & $\begin{array}{l}\text { Number of } \\
\text { Accessed }\end{array}$ & Publications & $\begin{array}{l}\text { Number of } \\
\text { Publications }\end{array}$ & Relevant \\
\hline "Transactional distance" & 81 & & 34 & \\
\hline "Online structure" & 68 & & 6 & \\
\hline "Online course structure" & 4 & & 1 & \\
\hline "Distance Course Structure" & 2 & & 1 & \\
\hline "Distance education and course structure" & 60 & & 12 & \\
\hline
\end{tabular}

The publication name, publication year, and author information of the studies included in the study are listed at the end of the bibliography.

\section{Coding Process}

Before content analysis, the literature was scanned by the researchers, the categories and codes of the structural dimension were removed, and the obtained data were noted on paper. Then the category/code list was finalized by seeking expert opinions before content analysis. In the next step, a word-based search was conducted on the identified categories and codes. After scanning, related parts were coded, homophonic clashes and unrelated words were excluded. During the word-based scanning phase, the analysis process was performed by scanning different words that could express the same code (social media, social network, Facebook, Twitter, Instagram, and alike). If a phrase referred to two different codes during the coding process, the coding was done in both codes. For example, since the phrase "synchronous chat" refers to the codes "online activities" and "chat", both codes were coded. Scanning excludes abstract, keywords, title, table, figure and graph, source/bibliography, appendices, footnotes, and words that occur more than once in the same sentence. Hyphen separated words at the end of the line are considered. The next step was to read the studies in depth and uncover the codes that could not be found with word-based scanning but were related to the structural dimension. Thus, new codes were added to the code list that was 
determined by the researchers after the preliminary study, and word-based scanning was performed again. Then, the coded sections were re-examined, and a control was performed. One month later, the coded sections were reviewed again by the researcher and coded by another expert. The research process was conducted between July 2020 and November 2020 . The keywords found and used, alternative keywords, documents found, words found, related words and number of words after word-based scanning and in-depth reading are shown in Table 2. The names of the simple categories were included in the screening process. The obtained simple category data were coded as "other" in the findings section.

Table 2. Keyword, alternative keyword, documents found, words found, related word, and the number of words after reading in-depth.

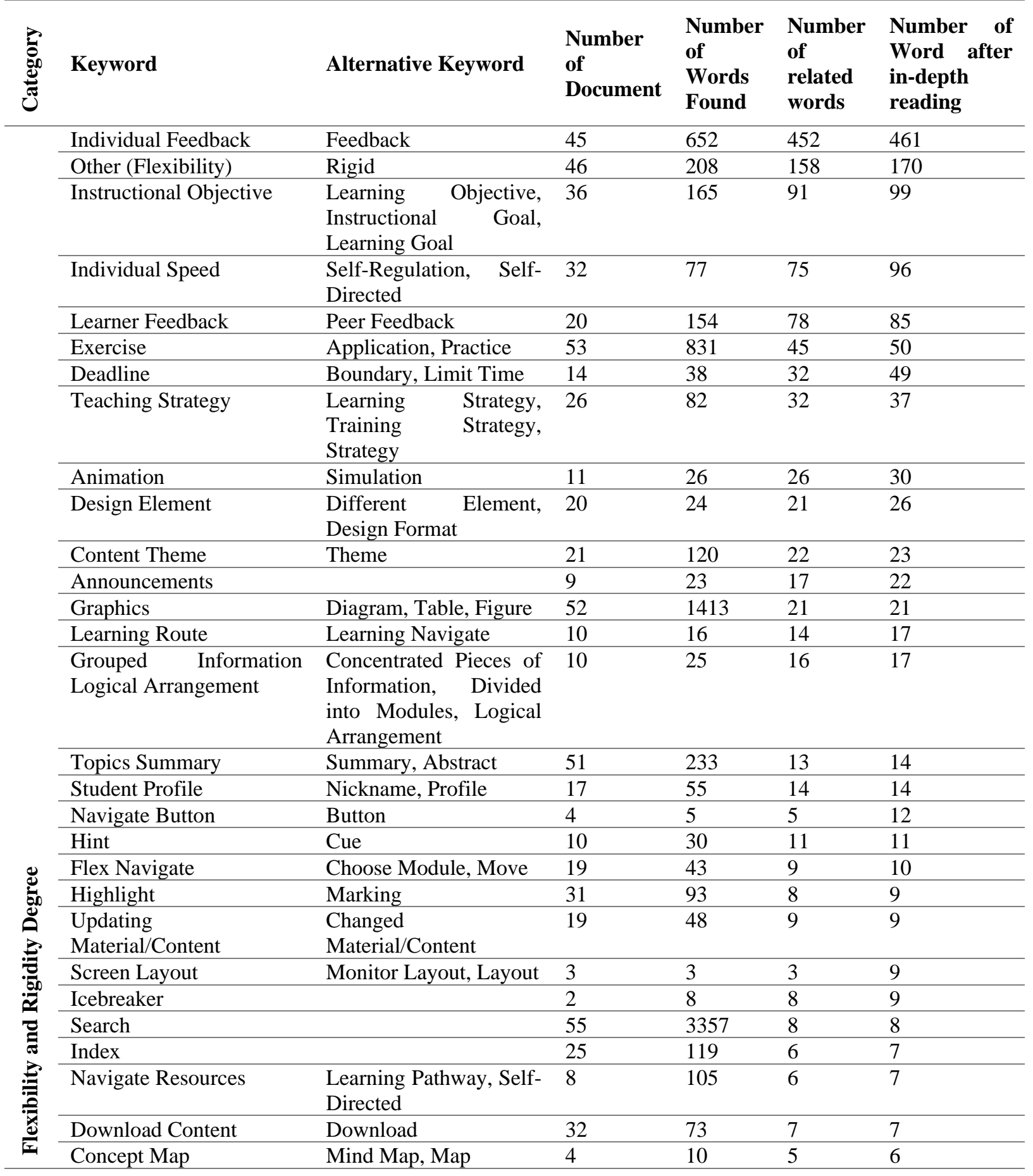




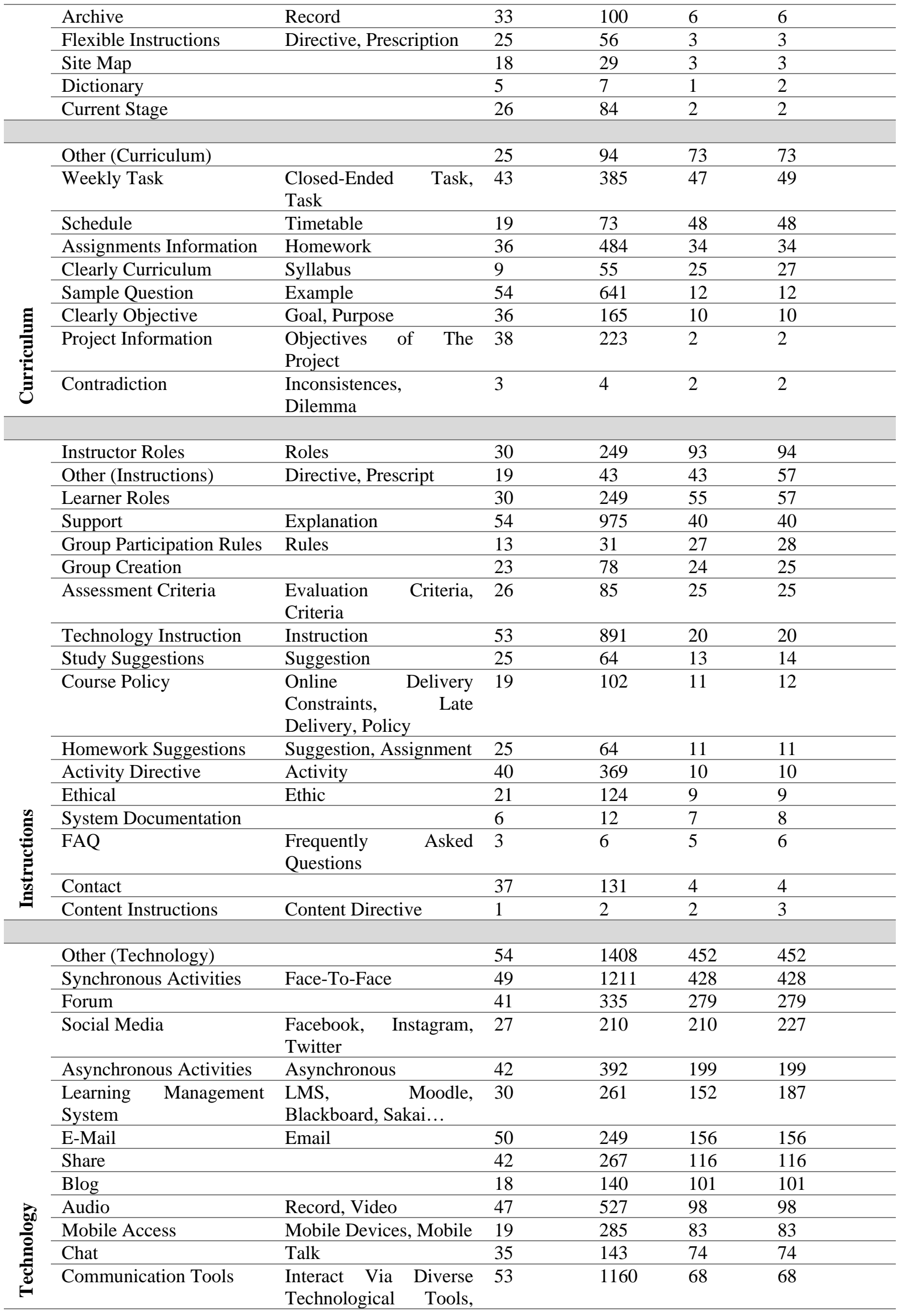




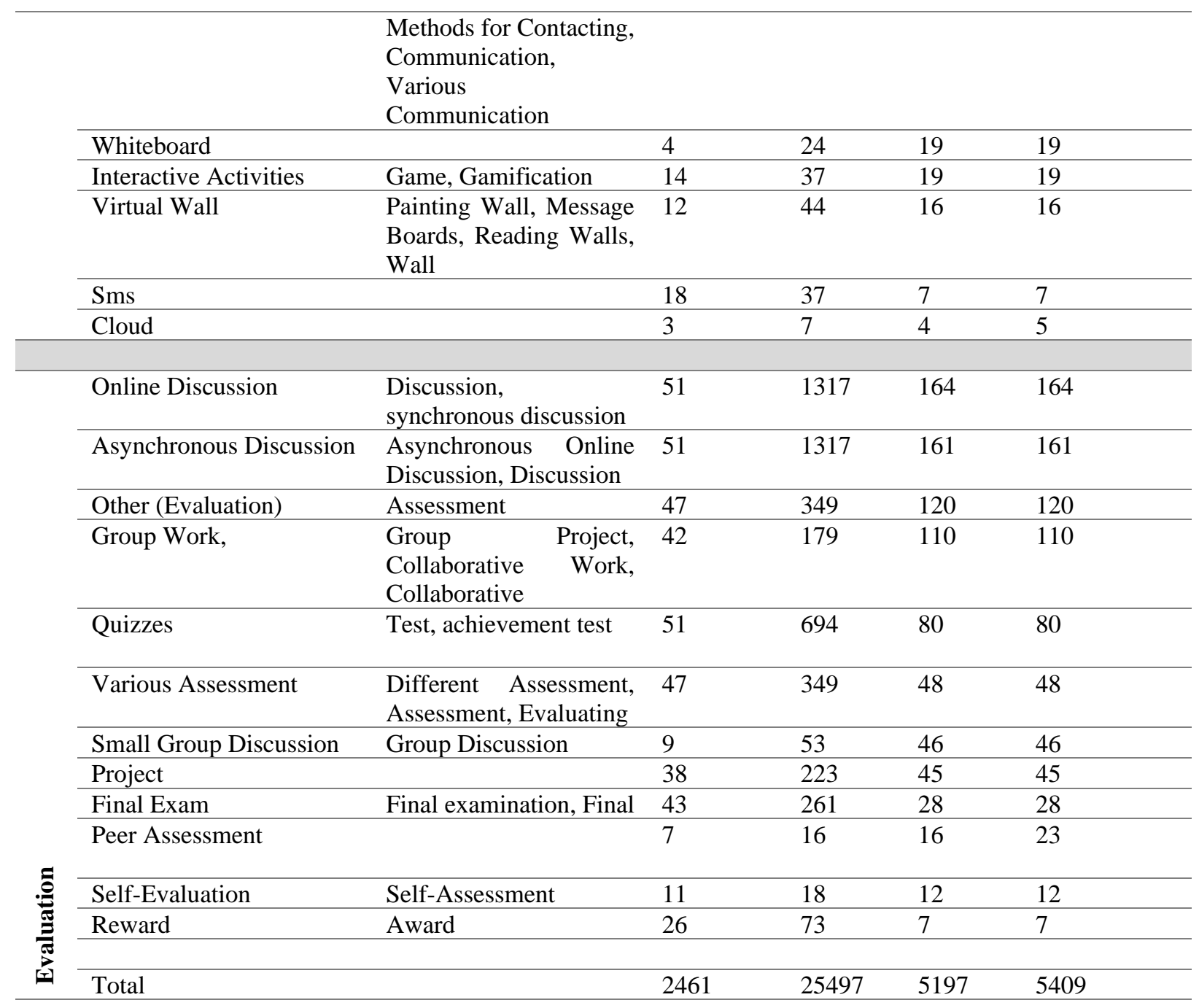

\section{Data Analysis}

The data of the study were analyzed using content analysis. According to Creswell (2016), the process of content analysis in qualitative research consists of the following steps: Preparation and organization of data, coding of data, reduction to themes by assigning codes, presentation and interpretation of results. In this study, the stated process of data analysis was taken as a reference. In the data preparation stage, the boundaries of the research were first established within which the research was conducted. The category created before the content analysis, after the stages of word-based scanning and in-depth reading within the code list, the categories and codes of each question were analyzed and interpreted in accordance with the research purpose. The data obtained is presented in graphs and tables. The purpose of this type of data presentation is to visualize the data and get an idea of the studies under study at a glance. Statistically, percentages and frequencies were used. After a general explanation under each table or graph, the similarities and differences found in the studies were analyzed in detail using the content analysis method according to the importance of the category. During the coding phase, the texts were carefully read and analyzed using the MAXQDA 2020 qualitative data analysis program. In order to better read the figures presented in the research results, the table of expressions developed by Yaylak (2020) was revised in the data visualization in accordance with the research. These visualizations and explanations are presented in Table 3. 
Table 3. Expressions used in data visualization.

Category
It is the visual that expresses the structures formed by the combination of codes.
It is the visual that expresses the codes under the category.
Visual expressing co-existence (strong) between category and code.
Visual expressing co-existence (weak) between category and code.

\section{Validity and Reliability}

Several methods were used to ensure the validity and reliability of the categories and codes. To ensure the reliability of the content analysis, researcher reliability was applied (Tavşancıl \& Aslan, 2001). For this reason, all data were recoded by another expert and the agreement (reliability coefficient) between the researcher and the expert was examined. The following formula proposed by Miles and Huberman (2016) was used to calculate the intercoder reliability percentage.

When data is put in the formula,

$$
\text { Reliability Percentage }=\frac{\text { Agreement }}{\text { Agreement }+ \text { Disagreement }} * 100
$$

$$
\text { Reliability Percentage }=\frac{5409}{5409+262} * 100 \rightarrow \frac{5409}{5671} * 100 \cong 95
$$

An agreement of about $95 \%$ was found between the coders. According to the coding control, which indicates internal consistency, inter-coder agreement is expected to be at least $80 \%$ (Miles \& Huberman, 1994; Patton, 2014). To ensure validity, the data collection method and inclusion and exclusion criteria are detailed (Brannigan et al., 2017). The number of studies on the topic and the studies included in the analysis are explained in detail. The data analysis, category and code writing processes have been explained in detail. The research process and time frame were given. Finally, an attempt was made to increase validity and reliability by presenting excerpts from the studies included in the study.

\section{Results}

\section{How is the flexibility-rigidity category of the structural dimension in the studies?}

The codes belonging to the flexibility-rigidity category were analyzed. MAXMaps Code Co-Occurrence Model belonging to the category is given in Figure 3. 


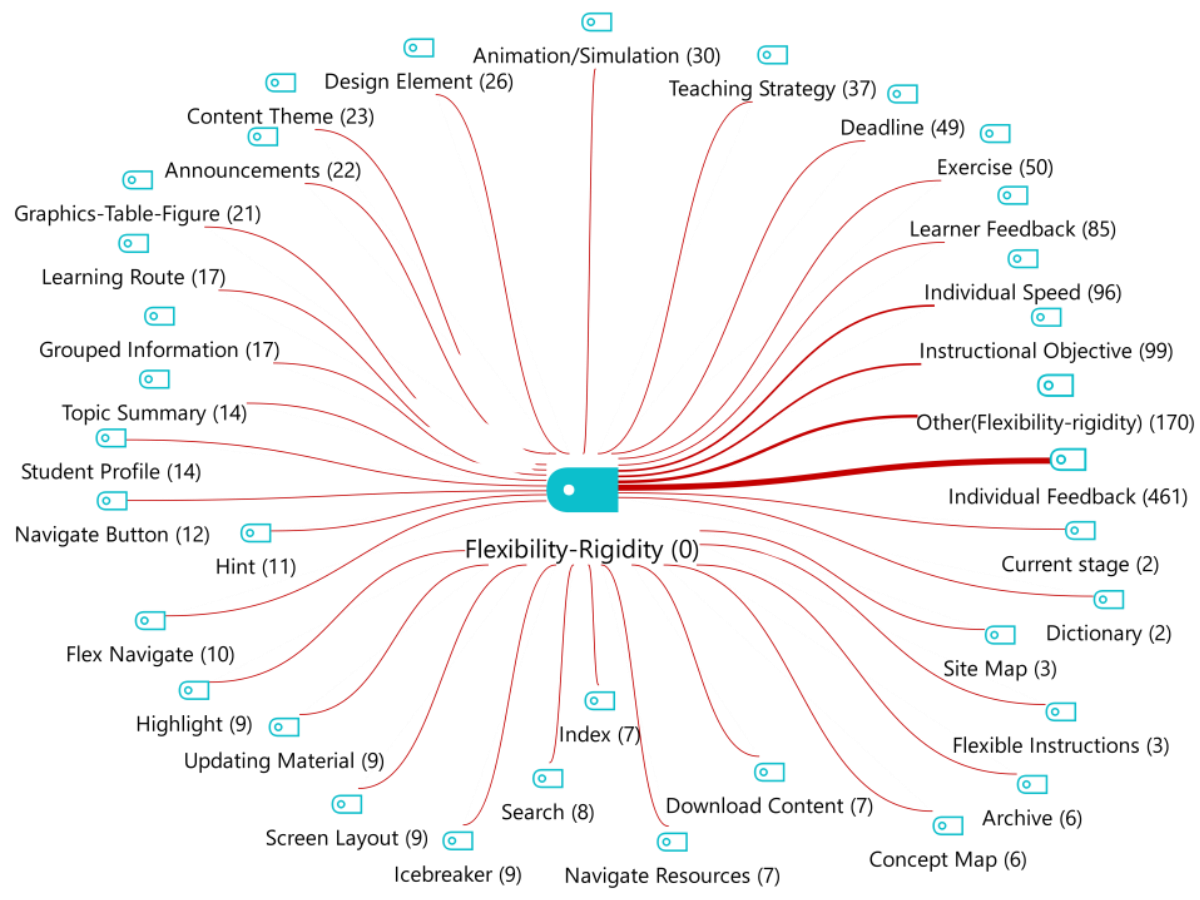

Figure 3. MAXMaps Code Co-Occurrence Model belonging to the flexibility-rigidity category.

Examining Figure 3, a total of 34 codes were found to belong to the flexibility-rigidity category, and 1351 codings were made. Simple expressions (flexibility-rigidity) that do not correspond to the codes of the flexibility-rigidity category but indicate the elasticity-rigidity category are coded under "the other" code. The Flexibility-Rigidity category explains the components that allow students to work flexibly online. The codes for the flexibility-rigidity category are listed in Table 4.

Table 4. Codes of flexibility-rigidity category

$\begin{array}{lll}\text { Codes } & \text { f } & \% \\ \text { Individual Feedback } & 461 & 34,12 \\ \text { Other (Flexibility-rigidity) } & 170 & 12,58 \\ \text { Instructional Objective } & 99 & 7,33 \\ \text { Individual Speed } & 96 & 7,11 \\ \text { Learner Feedback } & 85 & 3,29 \\ \text { Exercise } & 50 & 3,63 \\ \text { Deadline } & 49 & 2,74 \\ \text { Teaching Strategy } & 37 & 2,22 \\ \text { Animation/Simulation } & 30 & 1,92 \\ \text { Design Element } & 26 & 1,70 \\ \text { Content Theme } & 23 & 1,63 \\ \text { Announcements } & 22 & 1,55 \\ \text { Graphics-Table-Figure } & 21 & 1,26 \\ \text { Learning Route } & 17 & 1,26 \\ \text { Grouped Information } & 17 & 1,04 \\ \text { Topic Summary } & 14 & 1,04 \\ \text { Student Profile } & 14 & 0,89 \\ \text { Navigate Button } & 12 & 0,81 \\ \text { Hint } & 11 & 0,74 \\ \text { Flex Navigate } & 10 & 0,67 \\ \text { Highlight } & 9 & \end{array}$




\begin{tabular}{lcc} 
Updating Material & 9 & 0,67 \\
Screen Layout & 9 & 0,67 \\
Icebreaker & 9 & 0,67 \\
Search & 8 & 0,59 \\
Index & 7 & 0,52 \\
Navigate Resources & 7 & 0,52 \\
Download Content & 7 & 0,52 \\
Concept Map & 6 & 0,44 \\
Archive & 6 & 0,44 \\
Flexible Instructions & 3 & 0,22 \\
Site Map & 3 & 0,22 \\
Dictionary & 2 & 0,15 \\
Current stage & 2 & 0,15 \\
\hline TOTAL & 2 & $\mathbf{1 0 0 , 0 0}$
\end{tabular}

Looking at Table 4, it can be seen that the phrase "individual feedback" ( $\mathrm{f}=461 ; 34.12 \%$ ) is the most frequently used in the studies under the flexibility-rigidity category. It is followed by "other (flexibility rigidity)" ( $f=170 ; 12.58 \%$ ), "Instructional Objectives" ( $\mathrm{f}=99 ; 7.33 \%$ ) and "Individual Speed" ( $f=96 ; 7.11 \%$ ). Individual feedback means that the student receives individual responses from the instructor online. The other (flexibility-rigidity) code reflects simple expressions indicated as flexible or rigid in the online learning environment. The other (flexibility-rigidity) is that the online environment is flexible or rigid depending on the needs of the students. Instructional objectives whether the objectives are rigid or adaptable according to the course content and the level of the student. Individual speed is the presentation of content in the online environment according to the individual speed of the student. It can be seen that the code that has the least space under the flexibility-rigidity category is "Current stage" ( $\mathrm{f}=2 ; 0.15 \%)$.

\section{How is the curriculum category of the structural dimension fare in the studies?}

The codes belonging to the Curriculum category were analyzed. The MAXMaps Code Co-Occurrence Model belonging to this category are shown in Figure 4.

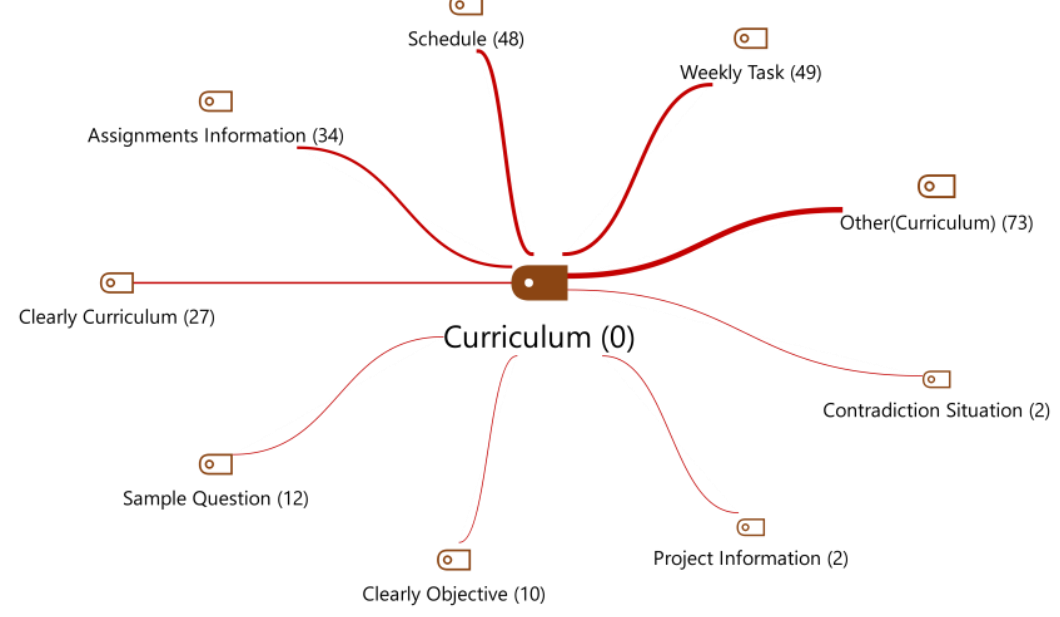

Figure 4. MAXMaps Code Co-Occurrence Model belonging to the curriculum category.

In examining Figure 4, a total of 9 codes were found to belong to the curriculum category, and 257 codings were made. Simple expressions (Curriculum) that do not correspond to the Curriculum category codes but refer to the curriculum category are coded under "the other" code. The curriculum category codes are listed in Table 5. 
Table 5. Codes of curriculum category

\begin{tabular}{lll}
\hline Codes & $\mathbf{f}$ & $\mathbf{\%}$ \\
\hline Other (Curriculum) & 73 & 28,40 \\
Weekly Task & 49 & 19,07 \\
Schedule & 48 & 18,68 \\
Assignments Information & 34 & 13,23 \\
Clearly Curriculum & 27 & 10,51 \\
Sample Question & 12 & 4,67 \\
Clearly Objective & 10 & 3,89 \\
Project Information & 2 & 0,78 \\
Contradiction Situation & 2 & 0,78 \\
\hline TOTAL & $\mathbf{2 5 7}$ & $\mathbf{1 0 0 , 0 0}$ \\
\hline
\end{tabular}

Looking at Table 5, it can be seen that the term "other (curriculum)" ( $\mathrm{f}=73 ; 28.40 \%$ ) is used most frequently in the studies under the category of curriculum. This code is followed respectively by "Weekly Task" ( $f=49 ; 19.07 \%$ ), "timetable" ( $f=48 ; 18.68 \%$ ) and "assignment information" ( $\mathrm{f}=34 ; 13.23 \%$ ). The code "other (curriculum)" reflects the lean expressions given as syllabus in the online learning environment. The Other (Curriculum) code reflects the effort expended to support student learning at the highest level. Weekly assignments reflect the tasks assigned to keep the student active in the online learning environment. The schedule is a detailed syllabus where the student can view the weekly schedule, instructor contact information, and grading criteria. The information on the scope of the assignments is to provide a detailed explanation of what exactly is expected from the submitted assignments. It can be seen that the code that finds the least space in the syllabus category is "conflicting situations" ( $\mathrm{f}=2 ; 0.78 \%)$.

\section{How is the instruction category of the structural dimension in the studies?}

The codes belonging to the Instruction category were analysed. The MAXMaps belonging to the category Code Co-Occurrence Model are shown in Figure 5.

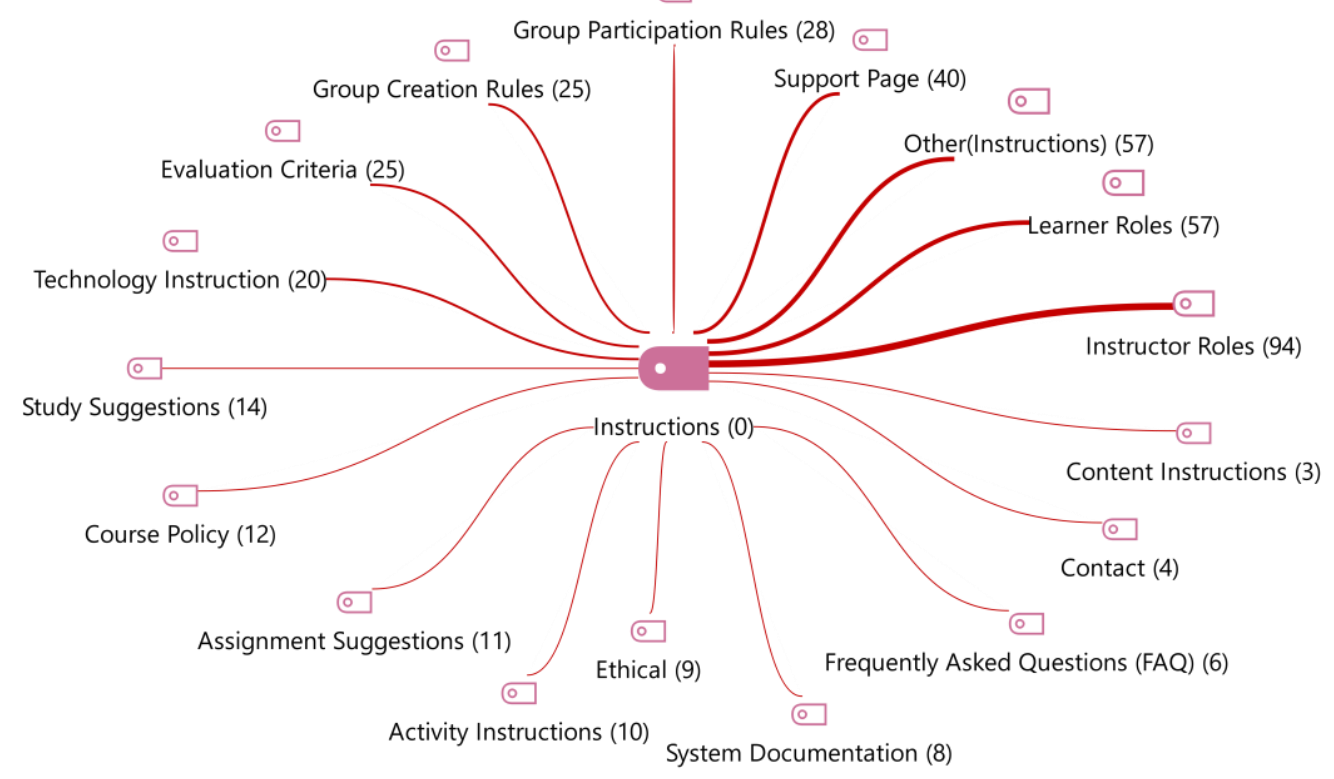

Figure 5. MAXMaps Code Co-Occurrence Model belonging to the instruction category. 
Looking at Figure 5, a total of 17 codes were found to belong to the instruction category, and 423 codings were made. Simple expressions (instructions) that do not correspond to the instruction category codes but refer to the instruction category are coded under "the other" code. The instruction category codes are listed in Table 6 .

Table 6. Codes of instructions category

\begin{tabular}{lll}
\hline Codes & f & \% \\
\hline Instructor Roles & 94 & 22,22 \\
Learner Roles & 57 & 13,48 \\
Other (Instructions) & 57 & 13,48 \\
Support Page & 40 & 9,46 \\
Group Participation Rules & 28 & 6,62 \\
Group Creation Rules & 25 & 5,91 \\
Evaluation Criteria & 25 & 5,91 \\
Used Technology Informing & 20 & 4,73 \\
Study Suggestions & 14 & 3,31 \\
Course Policy & 12 & 2,84 \\
Assignment Suggestions & 11 & 2,60 \\
Activity Instructions & 10 & 2,36 \\
Ethical & 9 & 2,13 \\
System Documentation & 8 & 1,89 \\
Frequently Asked Questions (FAQ) & 6 & 1,42 \\
Contact & 4 & 0,95 \\
Content Instructions & 3 & 0,71 \\
\hline TOTAL & $\mathbf{4 2 3}$ & $\mathbf{1 0 0 , 0 0}$ \\
\hline
\end{tabular}

Looking at Table 6, it can be seen that the expression " Instructor Roles " ( $\mathrm{f}=94 ; 22.22 \%$ ) is the most frequently used in the studies under the category of instruction. This code is followed by "Learner Roles" ( $\mathrm{f}=57 ; 13.48 \%$ ), "other (instruction)" ( $\mathrm{f}=57 ; 13.48 \%$ ) and "help page" ( $\mathrm{f}=40 ; 9.46 \%$ ). The role of the instructor is to inform the learners in advance about the role of the instructor in the online learning environment. The role of the learner is to give them rules on what to look for when participating in the online learning environment. The Miscellaneous (Instructions) code reflects the simple expressions that are given as instructions in the online learning environment. Other (Instructions) corresponds to the instructions presented to the learner in the online learning environment. The support page refers to the page where the learner can ask all kinds of questions and get explanations in the online learning environment. It can be seen that the code that finds the least space in the instruction category is "Content Instructions" ( $\mathrm{f}=3 ; 0.71 \%$ ).

\section{How is the technology category of the structure dimension in the studies?}

The codes belonging to the Technology category were analysed. The MAXMaps Code Co-Occurrence Model belonging to this category are shown in Figure 6. 


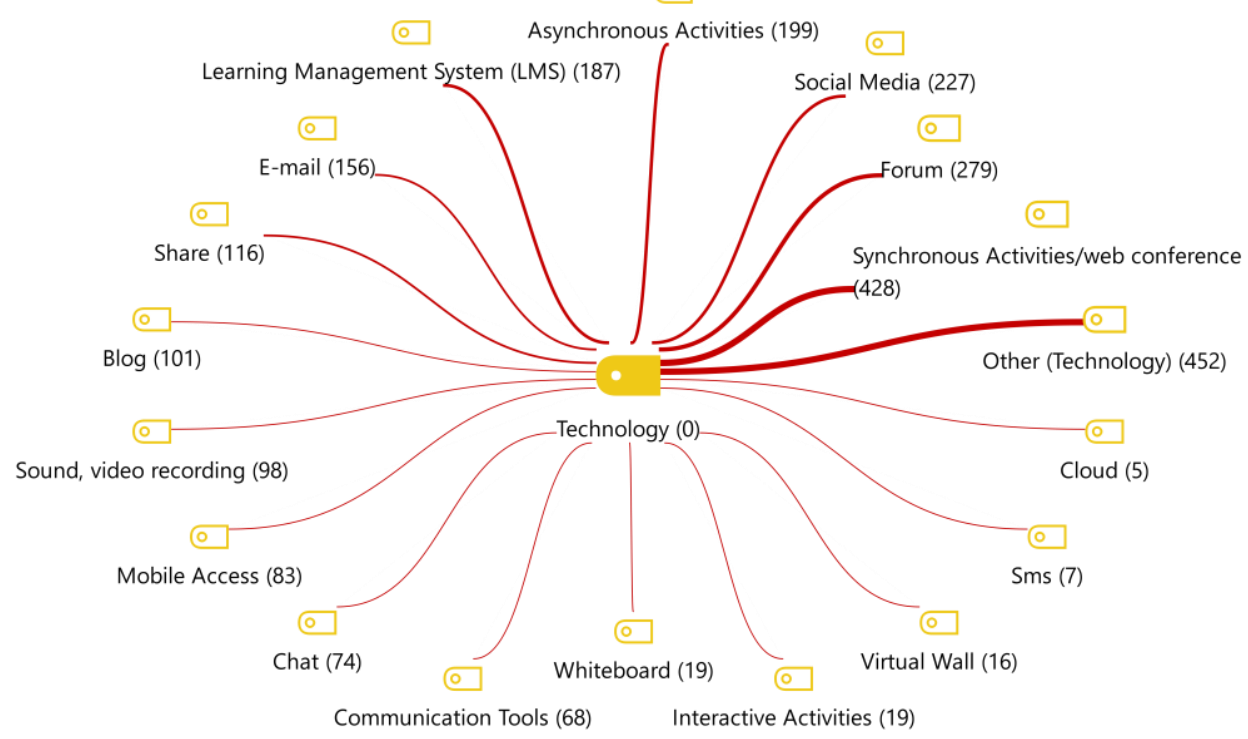

Figure 6. MAXMaps Code Co-Occurrence Model belonging to the technology category.

When Figure 6 was examined, a total of 18 codes belonging to the technology category were found, and 2534 codings were made. Simple expressions (technology) that do not correspond to the technology category codes but refer to the technology category are coded under "the other" code. The technology category codes are shown in Table 7.

Table 7. Codes of technology category

\begin{tabular}{lll}
\hline Codes & f & \% \\
\hline Other (Technology) & 452 & 17,84 \\
Synchronous Activities/web conference & 428 & 16,89 \\
Forum & 279 & 11,01 \\
Social Media & 227 & 8,96 \\
Asynchronous Activities & 199 & 7,85 \\
Learning Management System (LMS) & 187 & 7,38 \\
E-mail & 156 & 6,16 \\
Share & 116 & 4,58 \\
Blog & 101 & 3,99 \\
Sound, video recording & 98 & 3,87 \\
Mobile Access & 83 & 3,28 \\
Chat & 74 & 2,92 \\
Communication Tools & 68 & 2,68 \\
Whiteboard & 19 & 0,75 \\
Interactive Activities & 19 & 0,75 \\
Virtual Wall & 16 & 0,63 \\
Sms & 7 & 0,28 \\
Cloud & 70,20 \\
\hline TOTAL & 5 & 0,28 \\
\hline
\end{tabular}

Looking at Table 7, we see that the most frequently used expression in the studies under the category of technology is " other (technology) " ( $\mathrm{f}=452 ; 17.84 \%)$. This code is followed 
respectively by "Synchronous Activities /Web conference " ( $\mathrm{f}=428 ; 16.89 \%)$, "Forum" (f = $279 ; 11.01 \%$ ) and "Social Media" (f $=227 ; 8.96 \%$ ). The code "Other (Technology)" reflects simple expressions that refer to technology in the online learning environment. Synchronous activities/web conferencing refers to live course events offered online. Forum is the platform where learners can discuss with other learners and instructors. Social media enables the communication of all participants through one or more common platforms. It can be seen that the code that is least ranked in the technology category is "Cloud" ( $\mathrm{f}=5 ; 0.20 \%$ ).

\section{How is the evaluation category of the structure dimension in the studies?}

The codes belonging to the evaluation category were analysed. The MAXMaps Code Co-Occurrence Model belonging to this category are shown in Figure 7.

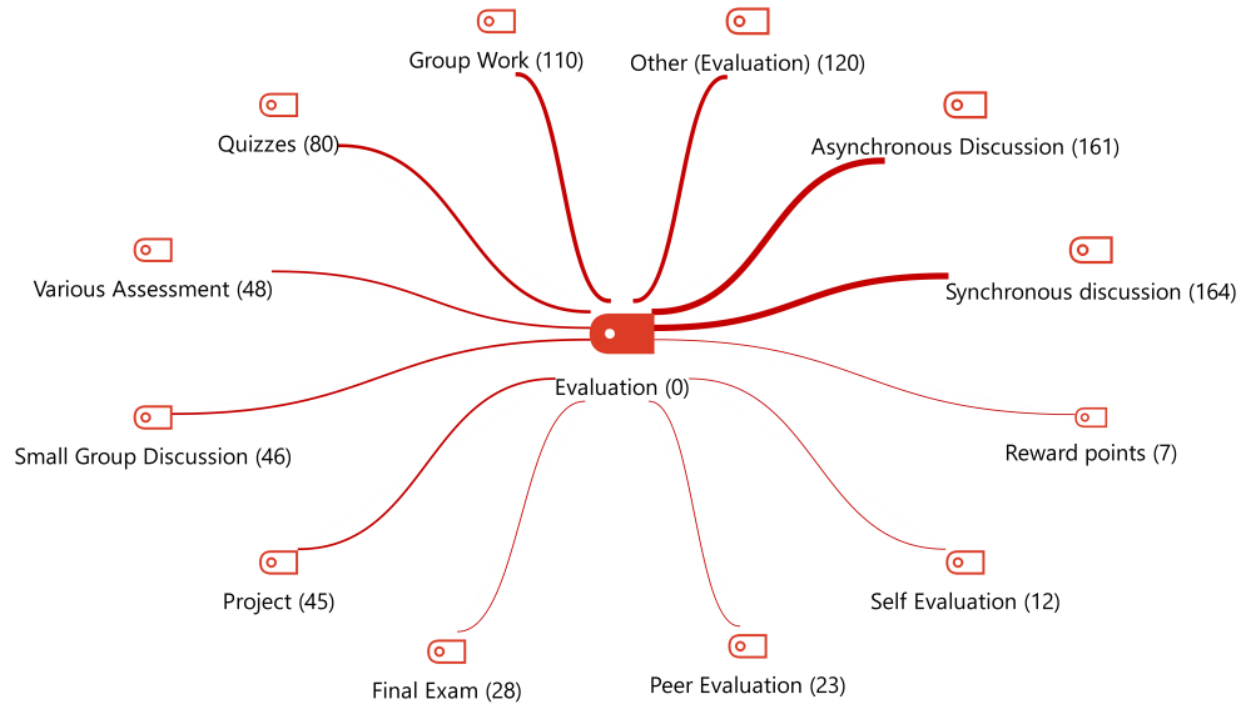

Figure 7. MAXMaps Code Co-Occurrence Model belonging to the evaluation category.

When Figure 7 was examined, a total of 12 codes belonging to the evaluation category were found, and 844 codings were made. Simple expressions (evaluation) that do not correspond to the evaluation category codes but indicate the evaluation category are coding under "the other" code. The codes of the evaluation category are given in Table 8.

Table 8. Codes of Evaluation category

\begin{tabular}{lll}
\hline Codes & $\mathbf{f}$ & $\mathbf{\%}$ \\
\hline Synchronous discussion & 164 & 19,43 \\
Asynchronous Discussion & 161 & 19,08 \\
Other (Evaluation) & 120 & 14,22 \\
Group Work & 110 & 13,03 \\
Quizzes & 80 & 9,48 \\
Various Assessment & 48 & 5,69 \\
Small Group Discussion & 46 & 5,45 \\
Project & 45 & 5,33 \\
Final Exam & 28 & 3,32 \\
Peer Evaluation & 23 & 2,73 \\
Self-Evaluation & 12 & 1,42 \\
Reward points & 7 & 0,83 \\
\hline TOTAL & 844 & 100,00 \\
\hline
\end{tabular}

Looking at Table 8, we see that the expression of "Synchronous discussion" ( $\mathrm{f}=164$; $19.43 \%$ ) is mostly used in the studies under the evaluation category. This code is respectively followed by, "Asynchronous Discussion" ( $\mathrm{f}=161 ; 19.08 \%$ ), "Other (Evaluation)" ( $\mathrm{f}=120$; 
$14.22 \%$ ) and "Group Work" ( $\mathrm{f}=110 ; 13,03 \%$ ). Synchronous discussion is the use of online communication of participants as a tool to evaluate. Asynchronous discussion is the use of offline communication of participants as a tool to evaluate. Other (evaluation) code, reflects plain expressions referred to as evaluation in the online learning environment. It is seen that the code that finds the least place in the evaluation category is "Reward points" ( $f=7 ; 0.83 \%)$.

\section{Which codes are the most studied codes and categories in the studies?}

The most used code and category in the studies were examined in terms of code overlap with other codes. The MAXMaps Code Co-Occurrence Model for the research question (Overlapping codes) is given in Figure 8. The most used code (individual feedback) and category (technology) are shown with large icons. Overlapping relation structures 5 and above are shown in large font sizes. 


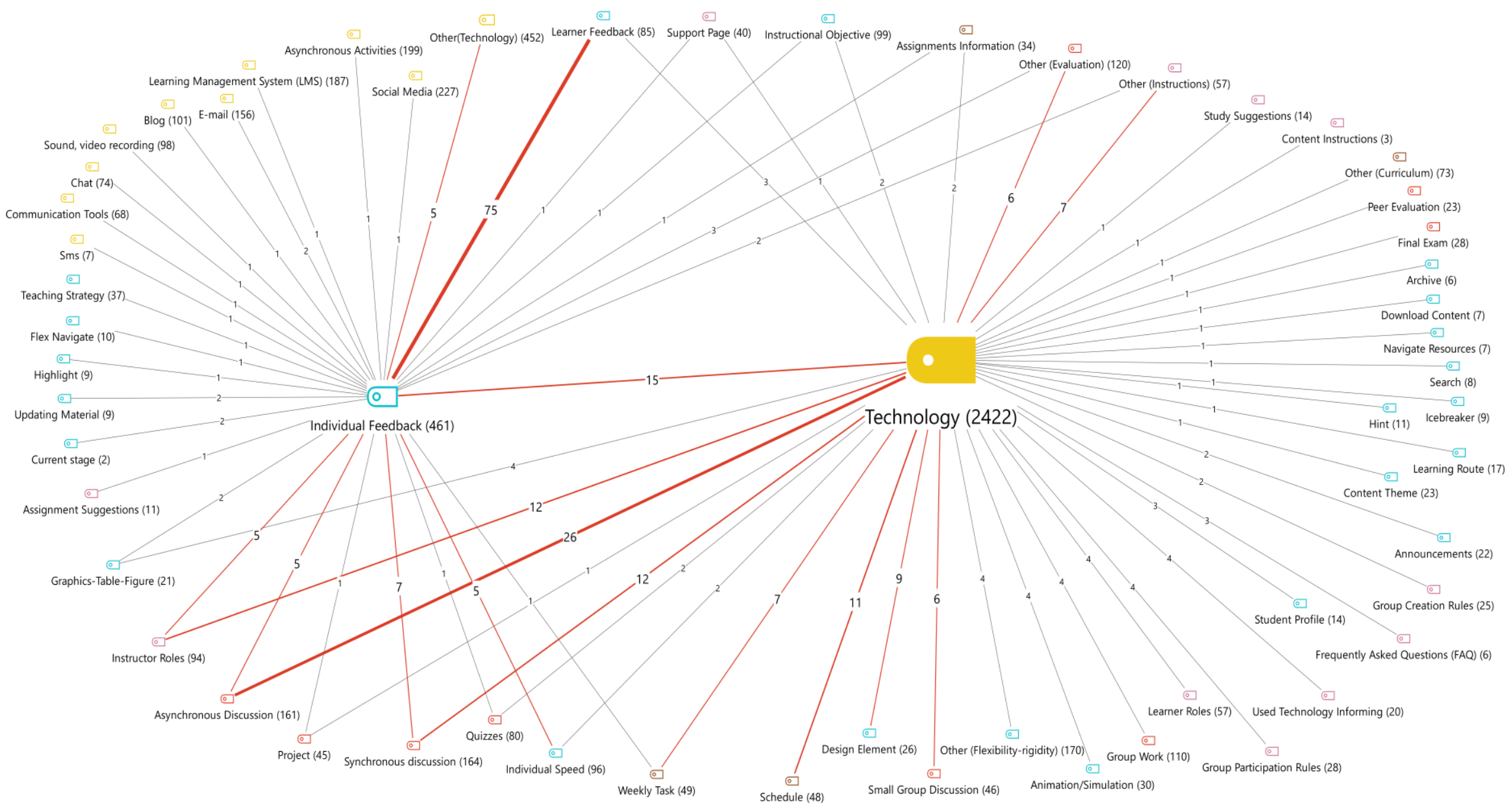

Figure 8. MaxMaps code co-occurrence model for the most used code and category (overlapping codes) 
For the overarching code structure analysis, the codes made under the Technology category were moved to the main Technology category. The joint analysis of the 2534 codes under the main category revealed that 112 joint codings were made. In order to perform the overlapping code structure with respect to technology category on unique codes, 112 codes were extracted before analysis and the study was performed with 2422 codes. Examining Figure 8, it can be seen that the individual feedback code $(f=461)$ and the technology category $(f=2422)$ are the most frequently examined in the studies. Looking at the overlapping code structure of the Individual Feedback code, it can be seen that it is most related to the Learner Feedback code ( $f=75$ ). This code is followed by the Technology ( $f=15$ ), Synchronous Discussion ( $f=7)$, Lecturer Role ( $f=5$ ), Individual Speed ( $f=5$ ), Asynchronous Discussion ( $f=5$ ), and Other (Technology) $(\mathrm{f}=5)$ codes. Looking at the overlapping code structure of the technology category, it can be seen that it is most strongly associated with the code asynchronous discussion ( $\mathrm{f}=26$ ). This code is followed by the codes individual feedback $(\mathrm{f}=15)$, synchronous discussion ( $\mathrm{f}=12$ ), instructor role $(\mathrm{f}=12)$, schedule $(\mathrm{f}=11)$, design element ( $\mathrm{f}$ $=9$ ), other (instruction) ( $f=7$ ), weekly assignment ( $f=7$ ), small group discussion $(f=6)$, and other (evaluation) $(f=6)$.

\section{Discussion and Conclusion}

The study sought to determine the components of the structure dimension, which is one of the components of distance learning. For this purpose, the structure dimension was analyzed under the main headings of degree of flexibility and rigidity, curriculum, instructions, technology and evaluation. There are not enough studies in the literature to address the findings of the research. However, since the structural dimension in distance education is also related to areas such as transactional distance, online environment design, and distance education applications, the discussions were supported with the studies conducted in these areas.

1351 codings were made in 33 codes related to the flexibility-rigidity category of the research. The flexibility-rigidity category is the second most emphasized category among the 5 categories analyzed. This importance given to the flexibility-rigidity category stems from the psychological factors that the design of flexible or rigid distance learning environments exerts on students. A flexible design of the structure allows students to move more independently in the environment. Saykili (2018) expressed flexibility as the freedom to determine learning objectives, activities, and choose assessment methods by explaining the phenomenon with student independence. In distance education, the flexibility of structure supports the student's sense of being closer to the environment and the sense of belonging. Studies (McIsaac \& Gunawardena, 1996; Collis \& Moonen, 2001; Thomas et al., 2014; Huang et al., 2015; Peacock et al., 2020) show that the strategies that enhance online students' sense of belonging (flexibility) support their learning experiences. This situation is consistent with the result of why the intense emphasis is placed on flexibility-rigidity, which is the second major categorical finding of the research. On the other hand, Huang, Chandra, DePaolo, and Simmons (2016) state that high structure, rigid environments where everything is planned in advance, can reduce transactional distance and support dialog. In Keegan (2005), face-to-face interaction is found to be more effective in supporting a sense of belonging and increasing success than flexibility of structure and student autonomy. Under the flexibility-rigidity category, the most individualized feedback code emerged. This situation is important to correct the student's mistakes and support the structuring process. Studies (Ali, 2018; Eggert \& Beutner, 2019) state that individual feedback plays an important 
role in teaching and can correct misconceptions. On the other hand, Hertzog and Swart (2018) state that individual audio feedback makes it difficult for students to have the relevant access due to the recording process and the associated bandwidth on the system. Similarly, Yiğit and Seferoğlu (2020) state as a result of their interviews with students that some students show negative attitudes towards individual feedback in the form of video.

257 Coding was done in 8 codes related to the curriculum category of the research. The curriculum category is the least highlighted among the 5 categories analyzed. As a reason, we can show that categories such as technology and flexibility rigidity are given more importance in distance education. Similar to the findings of this study, Bates (2014) in her study on open mass online courses mentions that little attention is paid to curriculum and more attention is paid to principles such as the use of social media, communication technologies, and evaluation. Studies of distance education literature (Zawacki-Richter, Baecker, \& Vogt, 2009; Anderson \& Dron, 2011) also show that fewer studies are conducted on curriculum design compared to other categories. On the other hand, Simonson et al. (2019) stated that curriculum design is crucial, referring to the fact that these environments should be developed to meet all the educational needs of students in today's conditions where many students participate in distance education. Similarly, Chugh, Ledger, and Shields (2017) speak to the critical importance of student success with the mandate they give to curriculum design in distance education.

423 codings were made in 16 codes that relate to the instructions category of the research. The instructions category is the fourth strongest category among the 5 categories studied. The factor that led to the coding of the instructions category at this intensity is the need for clear instructions regarding the instructor's role and learner participation in distance learning environments. The instructor is tasked with attracting learners and conducting activities that support their motivation, and instructions are given on how to do this (Cho \& Jonassen, 2009). Instructions are also given that require the use of technological tools such as social media tools to interact with learners at a maximum level (Cho \& Choi, 2017). Giving learners criteria for engagement leads learners to think more deeply about content and analyze problems better (Salter \& Conneely, 2015). On the other hand, Eggert and Beutner (2019) state that more than one defined role for the instructor leads to excessive instructor fatigue. Similarly, intensive structuring of learner engagement criteria leads to a decrease in learner autonomy (Yilmaz \& Yilmaz, 2019).

2534 Coding was done in 17 codes related to the technology category of the research. The technology category is the most emphasized category among the 5 categories analyzed. The reason that technology is used so extensively is because it effectively meets many educational needs such as interaction, access to content, communication, sharing, collaboration, and evaluation. Similar to the findings of the study, technology is considered important when it comes to interaction (Khan, 2005; Angelaki \& Mavroidis, 2013; Swerling, Thorson, \& Zerfass, 2014), access to content (Strachota, 2006; Fede, 2018), communication (Moore \& Kearsley, 2011; Guffey, Loewry, \& Griffin, 2019), collaboration (Feenberg, 2008; Eggert \& Beutner, 2019), and evaluation (Jelena \& Ana, 2019; Zydney, McKimmy, Lindberg, \& Schmidt, 2019). In today's form of distance education, technology is also critical to effective learning and teaching experiences. Similar to this finding, Moore and Diehl (2019) discuss how current technologies can be incorporated into education in their book, The Handbook of Distance Education, 4th Edition. On the other hand, findings regarding the positive impact of technology on students' perceptions of its use for communication and interaction are inconclusive (Dzakira, 2012). Technology is seen only as a tool in these studies. Clark (1983), 
one of the pioneers of the field, sees technology as only a tool for the delivery of education. Clark stated that "media are mere vehicles that deliver instruction but do not affect student achievement any more than the truck that delivers your food causes changes in our diet." The significance of this statement lies in the instructional methods rather than the use of technology, which has the main effect on learning (Clark, 1983, 1994, 2001). The unpredictability of technology is found to have a negative impact on learning experiences (Zydney et al., 2019). The reason given for this is connection problems during lessons or technical problems with the technology used. Saykili (2018) argues that although technological innovations play an important role in shaping the future of distance education, new technologies may not be as effective as previous technological innovations because the nature of communication does not seem to change.

844 codings were made in 11 codes related to the evaluation category of research. The evaluation category is the third most emphasized category among the 5 categories analyzed. This is due to the fact that evaluation is a frequently discussed topic in distance education. In addition, formative activities (group discussions, project assignments) and feedback, which are mostly preferred in distance education, appear as different evaluation components. Similar to the research findings, formative activities and feedback are found to be used in the evaluation process in many studies (Crisp, 2018; Gin, Lester, \& Blodgett, 2019). One of the main problems of distance education is the question of what the evaluation process should be and therefore what the nature of the evaluation should be. It can be stated that among the code structure revealed at the end of the research, formative evaluation is most preferred. This situation arises from the effort to support learners' development in the process due to the nature of distance education. Similar to the findings of the study (Piña, 2018; Brookhart, 2020), it can be seen that many researchers also use formative assessment in their studies. In addition, choosing adaptive methods in assessment makes the student more eager to use the system. Supporting this result, Barana et al (2015); Hattie and Timperley (2007) have highlighted the importance of adaptive and automated assessment systems. On the other hand, contrary to the research findings, it is seen that there are studies that argue that formative assessment can create a reliability problem. In these studies, components such as peer assessment and project tasks are criticized and it is mentioned that formative assessment can lead to more subjective results (Sajjadi, Alamgir, \& von Luxburg, 2016; Moreno-Marcos, Muñoz-Merino, Alario-Hoyos, Estévez-Ayres, and Delgado Kloos, 2018).

The most highlighted component (code) in the studies is individual feedback under the flexibility-rigidity category. The intensive use of the individual feedback code in distance learning environments is due to the fact that the stakeholders are not physically together and the need for suggestions from the stakeholders. The individual feedback code usually coincides with the learner feedback code. This is due to the fact that both codes serve the same purpose. Learner feedback in the studies refers to the feedback that learners give to each other. Individual feedback is the feedback process between learner-learner and teacherlearner. Therefore, both codes are usually preferred together in the distance education environment where they occur. Feedback can be given in text form as well as in audio or video form. Grigoryan (2017) and Howard (2020) emphasize that all three feedback methods (text, audio, video) should be used judiciously. However, studies show that textual feedback is the most commonly used in distance education. This is because textual feedback management allows instructors to provide feedback in a concise manner. Atwater et al (2017) also emphasize that textual feedback is the most preferred efficient, useful and essential feedback method. Students' feedback habits might also have led them to give more space to textual feedback. Borup et al (2015) state that students find it easier to receive feedback in 
textual form. On the other hand, giving textual feedback to students is found to require a lot of effort of the instructor (Chung \& Paredes, 2015). In the studies, the most highlighted category is technology. This is due to the fact that the technical infrastructure, one of the most basic needs of distance education, is equipped with technology. Moore and Kearsley (2011), in their definition of distance education, express the importance they give to technology with the task they give to communication technology. The research results show that the technology category has the most consistent code structure with the individual feedback code. It can be stated that this situation is caused by the use of technological platforms (social media, communication forms, SMS, forum, blog, virtual wall, and others.) in the individual feedback process. Angelaki and Mavroidis (2013) state that timely feedback can be given to students with the help of technological platforms such as forums. On the other hand, Eggert and Beutner (2019) state that technology does not always lead to positive outcomes, claiming that technological issues negatively affect students' pedagogy. Piña (2018), states that technology is not a panacea for all challenges of independent learning. He notes that it can be useful in distance education settings to the extent that it promotes self-regulation. For this reason, proper selection, planning, and implementation of technology are of great importance. Education providers should pay attention to the structural components when designing distance education environments. They should select appropriate technologies for the target audience and make the environment as flexible as possible. Policymakers should provide the technological infrastructure necessary for designers to designate distance education.

Depending on the results from the research the following are key considerations:

- Design the online learning environment to be as flexible as possible to make the student feel more comfortable and increase the sense of belonging,

- Incorporate all types of individual feedback methods (textual, audio-video) into the online learning environment,

- More attention should be paid to the least emphasized curriculum category and its components in the online learning environment, not forgetting the positive impact on student performance,

- Instructions regarding roles of instructors and students should be clearly stated,

- Technology should be planned in accordance with processes such as interaction, access to content, communication, sharing, collaboration and evaluation,

- Formative assessment should be given importance and more than one method of performance evaluation should be used,

- Since technological platforms are the basis for communication and feedback between stakeholders, it can be suggested that they should be used extensively in online learning environments.

\section{References}

Aghaee, N., Byron Jobe, W., Karunaratne, T., Smedberg, Å., Hansson, H., \& Tedre, M. (2016). Interaction gaps in PhD education and ICT as a way forward: Results from a study in Sweden. International Review of Research in Open and Distributed Learning, $17(3), 360-383$.

Alhih, M., Ossiannilsson, E., \& Berigel, M. (2017). Levels of interaction provided by online distance education models. Eurasia Journal of Mathematics, Science and Technology Education, 13(6), 2733-2748. https://doi.org/10.12973/eurasia.2017.01250a 
Ali, M. N. (2018). A Correlational Study of Types of Interactions and Student Satisfaction in Online Community College Mathematics, English, or Information Technology Courses. Morgan State University.

Alqurashi, E. (2019). Predicting student satisfaction and perceived learning within online learning environments. Distance Education, 40(1), 133-148. https://doi.org/10.1080/01587919.2018.1553562

Anderson, L. (2018). The Influence of Virtual Community Participation on Transactional Distance in an Online Computer Science Course. Arizona State University.

Anderson, T. (2003). Modes of interaction in distance education: Recent developments and research questions. In Handbook of Distance Education.

Anderson, T., \& Dron, J. (2011). Three generations of distance education pedagogy. International Review of Research in Open and Distributed Learning, 12(3), 80-97.

Angelaki, C., \& Mavroidis, I. (2013). Communication and Social Presence: The Impact on Adult Learners' Emotions in Distance Learning. European Journal of Open, Distance and e-Learning, 16(1), 78-93.

Atwater, C., Borup, J., Baker, R., \& West, R. E. (2017). Student perceptions of video communication in an online sport and recreation studies graduate course. Sport Management Education Journal, 11(1), 3-12.

Banas, J., \& Wartalski, R. (2019). Designing for Community in Online Learning Settings. Library Technology Reports. Retrieved https://www.journals.ala.org/index.php/ltr/article/view/6999

Barana, A., Marchisio, M., \& Rabellino, S. (2015). Automated assessment in mathematics. Proceedings - International Computer Software and Applications Conference, 3, 670 671. https://doi.org/10.1109/COMPSAC.2015.105

Bashir, K. (2019). Modeling E-Learning Interactivity, Learner Satisfaction and Continuance Learning Intention in Ugandan Higher Learning Institutions. International Journal of Education and Development Using Information and Communication Technology, $15(1), \mathrm{n} 1$.

Bates, T. (2014). Comparing xMOOCs and cMOOCs: philosophy and practice. Online Learning and Distance Education Resources.

Bazylova, B., Zhusupova, Z., Kazhigalieva, G., Onalbayeva, A., \& Kalinina, V. (2019). Subjective Understanding of The Student When Using Open Educational Resources. Periódico Tchê Química, 16, 613-630.

Berge, Z. (2002). Berge2002_ActiveInteractiveReflectiveLearning.pdf. The Quarterly Review of Distance Education, 3(2), 181-190.

Berge, Z. L., Muilenburg, L. Y., \& Haneghan, J. (2002). Barriers to distance education and training: Survey results. The Quarterly Review of Distance Education.

Bignoux, S., \& Sund, K. J. (2018). Tutoring executives online: what drives perceived quality? Behaviour and Information Technology, 37(7), 703-713. https://doi.org/10.1080/0144929X.2018.1474254

Blass, E., \& Davis, A. (2003). Building on solid foundations: establishing criteria for elearning development. Journal of Further and Higher Education, 27(3), 227-245.

Boelens, R., Wever, B. De, \& Voet, M. (2017). Four key challenges to the design of blended learning: A systematic literature review. Educational Research Review. Retrieved from https://www.sciencedirect.com/science/article/pii/S1747938X17300258

Bolliger, D U, \& Halupa, C. (2018). Online student perceptions of engagement, transactional distance, and outcomes. Distance Education. Retrieved from https://www.tandfonline.com/doi/abs/10.1080/01587919.2018.1476845

Bolliger, Doris U, \& Martin, F. (2018). Instructor and student perceptions of online student engagement strategies. Distance Education, 39(4), 568-583. 
Borup, J., West, R. E., \& Thomas, R. (2015). The impact of text versus video communication on instructor feedback in blended courses. Educational Technology Research and Development, 63(2), 161-184.

Bower, M. (2019). Technology-mediated learning theory. British Journal of Educational Technology, 50(3), 1035-1048.

Brannigan, C., Galvin, R., Walsh, M. E., Loughnane, C., Morrissey, E.-J., Macey, C., ... Horgan, N. F. (2017). Barriers and facilitators associated with return to work after stroke: a qualitative meta-synthesis. Disability and Rehabilitation, 39(3), 211-222.

Brookhart, S. (2020). Five Formative Assessment Strategies to Improve Distance Learning Outcomes for Students with Disabilities. NCEO Brief. Number 20. In National Center on Educational Outcomes. ERIC.

Çakır, R., Kara, M., \& Kukul, V. (2019). Adaptation of the online self-regulation questionnaire (OSRQ) in three types of interaction into Turkish: A validity and reliability study. Educational Technology Theory and .... Retrieved from https://toad.halileksi.net/sites/default/files/pdf/uc-etkilesim-turunde-cevrimici-ozduzenleme-olcegi-toad.pdf

Castillo-de Mesa, J., \& Gómez-Jacinto, L. (2020). Connectedness, Engagement, and Learning through Social Work Communities on LinkedIn. Psychosocial Intervention, 29(2), 103-112.

Cho, M.-H., Kim, Y., \& Choi, D. (2017). The effect of self-regulated learning on college students' perceptions of community of inquiry and affective outcomes in online learning. The Internet and Higher Education, 34, 10-17.

Cho, M., \& Jonassen, D. (2009). Development of the human interaction dimension of the Self-Regulated Learning Questionnaire in asynchronous online learning environments. Educational Psychology, 29(1), 117-138.

Chugh, R., Ledger, S., \& Shields, R. (2017). Curriculum design for distance education in the tertiary sector. Turkish Online Journal of Distance Education, 18(2), 4-15. https://doi.org/10.17718/tojde.306552

Chung, K. S. K., \& Paredes, W. C. (2015). Towards a social networks model for online learning \& performance. Journal of Educational Technology \& Society, 18(3), 240253.

Clark, R. E. (1983). Reconsidering research on learning from media. Review of Educational Research, 53(4), 445-459.

Clark, R. E. (1994). Media will never influence learning. Educational Technology Research and Development, 42(2), 21-29.

Clark, R. E. (2001). Learning from media: Arguments, analysis, and evidence. IAP.

Cohen, L., Manion, L., \& Morrison, K. (2007). Research methods in education. routledge.

Collis, B., \& Moonen, J. (2001). Flexible learning in a digital world: Experiences and expectations. Psychology press.

Creswell, J. W. (2016). Nitel araştırma yöntemleri: Beş yaklaşıma göre nitel araştırma ve araştırma deseni. Siyasal Kitabevi.

Crisp, B. R. (2018). From distance to online education: two decades of remaining responsive by one university social work programme. Social Work Education. Retrieved from https://www.tandfonline.com/doi/abs/10.1080/02615479.2018.1444157

Dede, C. (1996). The evolution of distance education: Emerging technologies and distributed learning. International Journal of Phytoremediation. https://doi.org/10.1080/08923649609526919

Desharnais, R. A., \& Limson, M. (2007). Designing and implementing virtual courseware to promote inquiry-based learning. Journal of Online Learning and Teaching, 3(1), 3039. 
Dewey, J. (1923). Democracy and education: An introduction to the philosophy of education. Macmillan.

Dockter, J. (2016). The Problem of Teaching Presence in Transactional Theories of Distance Education. Computers and Composition. https://doi.org/10.1016/j.compcom.2016.03.009

Dzakiria, H. (2012). Illuminating the Importance of Learning Interaction to Open Distance Learning (ODL) Success: A Qualitative Perspectives of Adult Learners in Perlis, Malaysia. European Journal of Open, Distance and E-Learning.

Eggert, D., \& Beutner, M. (2019). Developing the MultiDimensional Communication Channel Model (MDCC model) - A communication model for Virtual Classrooms. Proceedings of the Multidisciplinary Academic Conference, 48-71. MAC Praque Consulting s.r.o. Retrieved from http://search.ebscohost.com/login.aspx?direct=true\&db=asn\&AN=137297555\&lang=t r\&site=ehost-live

El-Bishouty, M. M., Aldraiweesh, A., Alturki, U., Tortorella, R., Yang, J., Chang, T.-W., \& Graf, S. (2019). Use of Felder and Silverman learning style model for online course design. Educational Technology Research and Development, 67(1), 161-177.

Elyakim, N., Reychav, I., Offir, B., \& ... (2019). Perceptions of transactional distance in blended learning using location-based mobile devices. Journal of Educational .... Retrieved from https://journals.sagepub.com/doi/abs/10.1177/0735633117746169

Falowo, R. O. (2007). Factors impeding implementation of web-based distance learning. Association for the Advancement of Computing in Education Journal.

Fede, B. (2018). Guidance in the Design and Implementation of an Online Mathematics Education Course. ERIC.

Feenberg, A. (2008). Critical theory of technology: An overview. In Information technology in librarianship: New critical approaches.

Friesen, N., \& Kuskis, A. (2013). Modes of interaction. Handbook of Distance Education, 351-371.

Galusha, J. M. (1998). Barriers to Learning in Distance Education. ERIC.

Garrison, D. R. (1991). Critical thinking and adult education: A conceptual model for developing critical thinking in adult learners. International Journal of Lifelong Education. https://doi.org/10.1080/0260137910100403

Garrison, R. (2000). Theoretical challenges for distance education in the 21st century: A shift from structural to transactional issues. International Review of Research in Open and Distance Learning.

Gavril, M., Andrei Mihalache, M., \& Lucian, T. (2019). E-Learning In Romanian Technical University For Mechanical Engineering Students. 110-123.

Gil-Jaurena, I., \& Domínguez, D. (2018). Teachers' roles in light of massive open online courses (MOOCs): Evolution and challenges in higher distance education. International Review of Education, 64(2), 197-219.

Gin, D. H. C., Lester, G. B., \& Blodgett, B. (2019). Forum on seminary teaching and formation online. Teaching Theology \& Religion, 22(1), 73-87.

Goh, C. F., Tan, O. K., Rasli, A., \& Choi, S. L. (2019). Engagement in peer review, learnercontent interaction and learning outcomes. International Journal of Information and Learning Technology, 36(5), 423-433. https://doi.org/10.1108/IJILT-04-2018-0038

Grigorovici, D., Nam, S., \& Russill, C. (2003). The effects of online syllabus interactivity on students' perception of the course and instructor. The Internet and Higher Education, $6(1), 41-52$. 
Grigoryan, A. (2017). Audiovisual commentary as a way to reduce transactional distance and increase teaching presence in online writing instruction: Student perceptions and preferences. Journal of Response to Writing, 3(1), 83-128.

Gronseth, S., \& Hebert, W. (2019). GroupMe: investigating use of mobile instant messaging in higher education courses. TechTrends. Retrieved from https://link.springer.com/article/10.1007/s11528-018-0361-y

Guffey, M., Loewry, D., \& Griffin, E. (2019). Business communication: Process and product . Toronto, ON: Nelson Education.

Gunawardena, C. N., \& McIsaac, M. S. (2013). Distance education. In Handbook of research on educational communications and technology (pp. 361-401). Routledge.

Hancock, T. B. (2018). The Relationship Between Online Students' Perceptions of the Quality of Online Instruction and New Students' Intent to Persist. Grand Canyon University.

Hattie, J., \& Timperley, H. (2007). The power of feedback. Review of Educational Research, 77(1), 81-112. https://doi.org/10.3102/003465430298487

Hertzog, P. E., \& Swart, A. J. (2018). Student perceptions of audio feedback in a designbased module for distance education. Global Journal of Engineering Education, 20(2), 100-106.

Holbeck, R., \& Hartman, J. (2018). Efficient strategies for maximizing online student satisfaction: Applying technologies to increase cognitive presence, social Presence, and teaching Presence. Journal of Educators Online, 15(3), n3.

Holland, A. A. (2019). Effective principles of informal online learning design: A theorybuilding metasynthesis of qualitative research. Computers \& Education, 128, 214226.

Holmberg, B., \& Ortner, G. E. (1991). Educational Theory and its Application to Distance Education. International Symposium on Distance Education in Theory and Practice.

House-Peters, L. A., Del Casino Jr, V. J., \& Brooks, C. F. (2019). Dialogue, inquiry, and encounter: Critical geographies of online higher education. Progress in Human Geography, 43(1), 81-103.

Howard, N. R. (2020). "How Did I Do?”: Giving learners effective and affective feedback. Educational Technology Research and Development, 1-4.

Huang, X, Chandra, A., DePaolo, C., Cribbs, J., \& ... (2015). Measuring transactional distance in web-based learning environments: An initial instrument development. ... of Open, Distance ... $\quad$ Retrieved from https://www.tandfonline.com/doi/abs/10.1080/02680513.2015.1065720

Huang, Xiaoxia, Chandra, A., DePaolo, C. A., \& Simmons, L. L. (2016). Understanding transactional distance in web-based learning environments: An empirical study. British Journal of Educational Technology, 47(4), 734-747. https://doi.org/10.1111/bjet.12263

Jelena, A. L., \& Ana, N. (2019). Designing e-learning environment based on student preferences: conjoint analysis approach. International Journal of Cognitive Research in Science, Engineering and Education, 7(3).

Jung, I. (2001). Building a theoretical framework of web-based instruction in the context of distance education. British Journal of Educational Technology, 32(5), 525-534.

Kara, M, \& Can, G. (2019). Master's Students' Perceptions and Expectations of Good Tutors and Advisors in Distance Education. International Review of Research in Open and .... Retrieved from https://www.erudit.org/en/journals/irrodl/1900-v1-n1irrodl04703/1061336ar/abstract/

Kara, Mehmet, \& Yildirim, Z. (2020). Identification of the optimal faculty behaviors for performance improvement in distance education. Asia Pacific Education Review, 21(1), 83-97. 
Karipi, E. (2019). Experiences of the Namibian College of Open Learning Tutors in Using Multimedia Resources in Distance Education. African Educational Research Journal, 7(1), 14-21.

Kayode, B. K. (2018). Effect of communication management on distance learners' cognitive engagement in Malaysian institutions of higher learning. International Review of Research in Open and ... https://www.erudit.org/en/journals/irrodl/1900-v1-n1-irrod104233/1055526ar/abstract/

Keegan, D. (2005). Theoretical principles of distance education. Routledge.

Khan, B. H. (2005). Managing e-learning: Design, delivery, implementation, and evaluation. IGI Global.

Kyei-Blankson, L., Ntuli, E., \& Donnelly, H. (2019). Establishing the importance of interaction and presence to student learning in online environments. Journal of Interactive .... Retrieved from https://www.learntechlib.org/p/161956/

Lawyer, D. J. (2018). Freshman English Composition, Course Modality, Transactional Distance Theory, and Student Success. ProQuest LLC.

Lemak, D. J., Shin, S. J., Reed, R., \& Montgomery, J. C. (2005). Technology, transactional distance, and instructor effectiveness: An empirical investigation. Academy of Management Learning \& Education, 4(2), 150-159.

Marchisio, M., Sacchet, M., \& Salusso, D. (2019). Instructional design to "train the trainers": the start@ unito project at the university of Turin. International Conference ELearning 2019 Part of the Multi Conference on Computer Science and Information Systems 2019, 195-202. Iadis Press.

McIsaac, M. S., \& Gunawardena, C. N. (1996). Distance education. Handbook of Research for Educational Communications and Technology, 403-437.

Miles, M B, \& Huberman, A. M. (2016). Genişletilmiş bir kaynak kitap: nitel veri analizi. SA Altun, A. Ersoy Çev.). Ankara: Pegem Akademi.

Miles, Matthew B, \& Huberman, A. M. (1994). Qualitative data analysis: An expanded sourcebook. sage.

Moher, D., Liberati, A., Tetzlaff, J., \& Altman, D. G. (2010). Preferred reporting items for systematic reviews and meta-analyses: the PRISMA statement. Int J Surg, 8(5), 336341. https://doi.org/10.1016/j.ijsu.2010.02.007

Moher, D., Liberati, A., Tetzlaff, J., Altman, D. G., \& Group, P. (2009). Preferred reporting items for systematic reviews and meta-analyses: the PRISMA statement. PLoS Med, 6(7), e1000097.

Moore, M. G. (1989). Editorial: Three types of interaction. American Journal of Distance Education. https://doi.org/10.1080/08923648909526659

Moore, M. G. (1993). Theory of transactional distance. In Theoretical principles of distance education. https://doi.org/doi:10.4324/9780203983065

Moore, M. G. M., \& Kearsley, G. (2011). Distance education: A sysyems view of online learning. In Distance education:

Moreno-Marcos, P. M., Muñoz-Merino, P. J., Alario-Hoyos, C., Estévez-Ayres, I., \& Delgado Kloos, C. (2018). Analysing the predictive power for anticipating assignment grades in a massive open online course. Behaviour \& Information Technology, 37(10-11), 1021-1036.

Muljana, P. S., \& Luo, T. (2019). Factors contributing to student retention in online learning and recommended strategies for improvement: A systematic literature review. Journal of Information Technology .... Retrieved from https://digitalcommons.odu.edu/stemps_fac_pubs/80/

Naidu, S. (2018). Editorial:to interact or not to interact is NOT the question! Distance Education, 39(3), 277-280. 
Olpak, Y Z, \& Çakmak, E. K. (2018). Learning strategies predicting the perception of social presence of distance education students. Bartın University Faculty of Education .... Retrieved from https://dergipark.org.tr/en/pub/buefad/article/365218

Olpak, Yusuf Ziya, \& Çakmak, E. K. (2014). Effects of Different Feedback Strategies on Students' Perceptions of Social Cognitive and Teaching Presence and Academic Achievements in Online Learning Environments. Journal of Ahi Evran University Kirşehir Faculty of Education, 15(2), 243-261.

Özbay, Ö., \& Sarıca, R. (2019). The Trends of Studies Regarding Flipped Classroom: A Systematic Review of Literature. Ahi Evran University Journal of Social Sciences Institute, 5(2), 332-348.

Patton, M. Q. (2014). Qualitative research \& evaluation methods: Integrating theory and practice. Sage publications.

Pawan, F., Paulus, T. M., Yalcin, S., \& Chang, C. F. (2003). Online learning: Patterns of engagement and interaction among in-service teachers. Language Learning and Technology, 7(3), 119-140.

Peacock, S., Cowan, J., Irvine, L., \& Williams, J. (2020). An Exploration Into the Importance of a Sense of Belonging for Online Learners. The International Review of Research in Open and Distributed Learning, 21(2 SE-Research Articles), 18-35. https://doi.org/10.19173/irrodl.v20i5.4539

Piña, A. A. (2018). AECT Instructional Design Standards for Distance Learning. TechTrends, 62(3), 305-307.

Quong, J., Snider, S. L., \& Early, J. (2018). Reducing transactional distance in online and blended courses through the use of a closed social media platform. Journal of Educational .... Retrieved from https://journals.sagepub.com/doi/abs/10.1177/0047239518766654

Rhode, J. F. (2009). Interaction equivalency in self-paced online learning environments: An exploration of learner preferences. International Review of Research in Open and Distance Learning. https://doi.org/10.19173/irrodl.v10i1.603

Rogers-Shaw, C., Carr-Chellman, D. J., \& Choi, J. (2018). Universal design for learning: Guidelines for accessible online instruction. Adult Learning. Retrieved from https://journals.sagepub.com/doi/abs/10.1177/1045159517735530

Saba, F. (2016). Theories of Distance Education: Why They Matter. New Directions for Higher Education. https://doi.org/10.1002/he.20176

Sajjadi, M. S. M., Alamgir, M., \& von Luxburg, U. (2016). Peer grading in a course on algorithms and data structures: Machine learning algorithms do not improve over simple baselines. Proceedings of the Third (2016) ACM Conference on Learning@ Scale, 369-378.

Salter, N. P., \& Conneely, M. R. (2015). Structured and unstructured discussion forums as tools for student engagement. Computers in Human Behavior, 46, 18-25.

Sarrab, M., Al-Shihi, H., Al-Manthari, B., \& Bourdoucen, H. (2018). Toward educational requirements model for Mobile learning development and adoption in higher education. TechTrends, 62(6), 635-646.

Sato, T., \& Haegele, J. A. (2018). Undergraduate Kinesiology Students' Experiences in Online Motor Development Courses. Online Learning. Retrieved from https://digitalcommons.odu.edu/hms_fac_pubs/72/

Saykili, A. (2018). Distance Education: Definitions, Generations, Key Concepts and Future Directions. International Journal of Contemporary Educational .... Retrieved from https://eric.ed.gov/?id=EJ1207516 
Schreiber, B. R., \& Jansz, M. (2020). Reducing distance through online international collaboration. ELT Journal. Retrieved from https://academic.oup.com/eltj/articleabstract/74/1/63/5650732

Seaman, J., Allen, I. E., \& Seaman, J. (2018). Grade increase: Tracking distance education in the United States. Babson Survey Research Group, 1-49.

Simonson, M, Zvacek, S. M., \& Smaldino, S. (2019). Teaching and Learning at a Distance: Foundations of Distance Education 7th Edition. books.google.com. Retrieved from https://books.google.com/books?hl=en\&lr=\&id=qh-

3DwAAQBAJ\&oi=fnd\&pg=PR1\&dq=transactional+distance+online+course+online+ course+structure \&ots=EcFgyZ9jIO\&sig=FVrX850vZXGXp70ogpAIRIIXRRc

Simonson, Michael. (2019). Research in Distance Education: A Summary. Quarterly Review of Distance Education, 20(3), 31-52.

Sims, R. (1997). Interactivity: A forgotten art? Computers in Human Behavior, 13(2), 157180. https://doi.org/10.1016/S0747-5632(97)00004-6

Stöhr, C., Demazière, C., \& Adawi, T. (2020). The polarizing effect of the online flipped classroom. Computers \& Education. Retrieved from https://www.sciencedirect.com/science/article/pii/S0360131519303392

Strachota, E. (2006). The use of survey research to measure student satisfaction in online courses. Midwest Research to Practice Conference in Adult Continuing and Community Education, University of Missouri-St. Louis.

Swerling, J., Thorson, K., \& Zerfass, A. (2014). The role and status of communication practice in the USA and Europe. Journal of Communication Management.

Tavşancıl, E., \& Aslan, A. E. (2001). Sözel, yazılı ve diğer materyaller için içerik analizi ve uygulama örnekleri[Content Analysis and Application Examples for Verbal, Written, and Other Materials]. Epsilon.

Thomas, L., Herbert, J., \& Teras, M. (2014). A sense of belonging to enhance participation, success and retention in online programs. The International Journal of the First Year in Higher Education, 5(2), 69-80. https://doi.org/10.5204/intjfyhe.v5i2.233

Thorpe, M. (2014). Online interaction: Why it matters to use forums strategicallyOnline strategically. Distance Education in China, (7), 3.

Uppal, M. A., Ali, S., \& Gulliver, S. R. (2018). Factors determining e-learning service quality. British Journal of Educational Technology, 49(3), 412-426.

Vaughn, S. D. (2018). Online Doctoral Student Satisfaction as Influenced by Personality and Transactional Distance. ERIC.

Vonderwell, S., \& Zachariah, S. (2005). Factors that influence participation in online learning. Journal of Research on Technology in Education, 38(2), 213-230.

Vygotsky, L. S. (1980). Mind in society: The development of higher psychological processes. Harvard university press.

Wakeling, V., Doral, M., Robertson, P. R., \& Patrono, M. (2018). Perceptions of Undergraduate Students of Student-Regulated Online Courses. Online Journal of Distance Learning Administration, 21(3), n3.

Weidlich, J., \& Bastiaens, T. J. (2018). Technology matters - The impact of transactional distance on satisfaction in online distance learning. International Review of Research in Open and Distance Learning, 19(3), 222-242. https://doi.org/10.19173/irrodl.v19i3.3417

Xiao, J. (2017). Learner-content interaction in distance education: The weakest link in interaction research. Distance Education, 38(1), 123-135. https://doi.org/10.1080/01587919.2017.1298982 
Xing, W. (2019). Exploring the influences of MOOC design features on student performance and persistence. Distance Education. Retrieved from https://www.tandfonline.com/doi/abs/10.1080/01587919.2018.1553560

Yates, A., Brindley-Richards, W., \& Thistoll, T. (2020). Student engagement in distancebased vocational education. Journal of Open, Flexible, and Distance Learning, 18(2), $29-43$.

Yaylak, E. (2020). A Case Study on the Social Studies Interactive Notebook (SSIN) Practices. Education and Science, 1-25. https://doi.org/10.15390/eb.2020.8809

Yazici, A., Altas, I., Wagga-Australia, W., \& Demiray, U. (2001). Distance education on the net: A model for developing countries. Turkish Online Journal of Distance Education, 2(2), 24-35.

Yiğit, M. F., \& Seferoğlu, S. S. (2020). Investigating the Effect of Video-Based Feedback on Perceived Feedback Quality1. Pamukkale University Journal of Education, 1-31.

Yilmaz, F. G. K., \& Yilmaz, R. (2019). The impact of feedback form on transactional distance and critical thinking skills in online discussions. Innovations in Education and Teaching International.

Yilmaz, R., \& Yilmaz, F. G. K. (2019). Assigned roles as a structuring tool in online discussion groups: comparison of transactional distance and knowledge sharing behaviors. Journal of Educational ... Retrieved from https://journals.sagepub.com/doi/abs/10.1177/0735633118786855

Zawacki-Richter, O., Bäcker, E. M., \& Vogt, S. (2009). Review of distance education research (2000 to 2008): Analysis of research areas, methods, and authorship patterns. International Review of Research in Open and Distributed Learning, 10(6), 21-50.

Zilka, G. C., Rahimi, I. D., \& Cohen, R. (2019). Sense of challenge, threat, self-efficacy, and motivation of students learning in virtual and blended courses. American Journal of Distance .... Retrieved from https://www.tandfonline.com/doi/abs/10.1080/08923647.2019.1554990

Zimmerman, T. D. (2012). Exploring learner to content interaction as a success factor in online courses | Zimmerman | The International Review of Research in Open and Distance Learning. International Review of Research in Open and Distance Learning, 13(4), 152-165. Retrieved from http://www.irrodl.org/index.php/irrodl/article/view/1302

Zydney, J. M., McKimmy, P., Lindberg, R., \& Schmidt, M. (2019). Here or there instruction: Lessons learned in implementing innovative approaches to blended synchronous learning. TechTrends, 63(2), 123-132.

Studies included in the research.

\begin{tabular}{llll}
\hline Number & Study Name & $\begin{array}{c}\text { Study } \\
\text { Year }\end{array}$ & Author/s (APA 6) \\
\hline $\mathbf{1}$ & $\begin{array}{l}\text { A Correlational Study Of Types Of Interactions And Student } \\
\text { Satisfaction In Online Community College Mathematics, } \\
\text { English, And Information Technology Courses }\end{array}$ & & (Ali, 2018) \\
& $\begin{array}{l}\text { Predicting student satisfaction and perceived learning within } \\
\text { online learning environments }\end{array}$ & 2019 & (Alqurashi, 2019) \\
\hline $\mathbf{2}$ & Designing for Community in Online Learning Settings & 2019 & (Banas \& Wartalski, \\
\hline $\mathbf{4}$ & $\begin{array}{l}\text { Modeling E-Learning Interactivity, Learner Satisfaction and } \\
\text { Continuance Learning Intention in Ugandan Higher Learning }\end{array}$ & & (Bashir, 2019) \\
& Institutions & & \\
\hline $\mathbf{5}$ & $\begin{array}{l}\text { Subjective Understanding of The Student When Using Open } \\
\text { Educational Resources }\end{array}$ & & (Bazylova, \\
& & &
\end{tabular}




\begin{tabular}{|c|c|c|c|}
\hline & & & $\begin{array}{l}\text { Kazhigalieva, } \\
\text { Onalbayeva, } \\
\text { Kalinina, 2019) }\end{array}$ \\
\hline 6 & Tutoring executives online: what drives perceived quality? & 2018 & $\begin{array}{l}\text { (Bignoux \& Sund, } \\
\text { 2018) }\end{array}$ \\
\hline 7 & Technology-mediated learning theory & 2019 & (Bower, 2019) \\
\hline 8 & $\begin{array}{l}\text { Connectedness, Engagement, and Learning through Social Work } \\
\text { Communities on LinkedIn }\end{array}$ & 2020 & $\begin{array}{l}\text { (Castillo-de Mesa \& } \\
\text { Gómez-Jacinto, 2020) }\end{array}$ \\
\hline 9 & $\begin{array}{l}\text { From distance to online education: two decades of remaining } \\
\text { responsive by one university social work programme }\end{array}$ & 2018 & (Crisp, 2018) \\
\hline 10 & $\begin{array}{l}\text { Adaptation Of the AutherOnlıne Self-Regulation Questionnaire } \\
\text { (Osrq) In Three Types Of Interaction Into Turkish: A Valıdity } \\
\text { And Reliability Study }\end{array}$ & 2019 & $\begin{array}{l}\text { (Çakır, Kara, } \\
\text { Kukul, 2019) }\end{array}$ \\
\hline 11 & $\begin{array}{l}\text { Online student perceptions of engagement, transactional } \\
\text { distance, and outcomes }\end{array}$ & 2018 & $\begin{array}{l}\text { (D U Bolliger \& } \\
\text { Halupa, 2018) }\end{array}$ \\
\hline 12 & $\begin{array}{l}\text { Instructor and student perceptions of online student engagement } \\
\text { strategies }\end{array}$ & 2018 & $\begin{array}{l}\text { (Doris U Bolliger \& } \\
\text { Martin, 2018) }\end{array}$ \\
\hline 13 & $\begin{array}{l}\text { Developing the MultiDimensional Communication Channel } \\
\text { Model (MDCC model)- A communication model for Virtual } \\
\text { Classrooms }\end{array}$ & 2019 & $\begin{array}{l}\text { (Eggert \& Beutner, } \\
\text { 2019) }\end{array}$ \\
\hline 14 & $\begin{array}{l}\text { Use of Felder and Silverman learning style model for online } \\
\text { course design }\end{array}$ & 2019 & $\begin{array}{l}\text { (El-Bishouty et al., } \\
\text { 2019) }\end{array}$ \\
\hline 15 & $\begin{array}{l}\text { Perceptions of transactional distance in blended learning using } \\
\text { location-based mobile devices }\end{array}$ & 2019 & $\begin{array}{l}\text { (Elyakim, Reychav, } \\
\text { Offir, \& ..., 2019) }\end{array}$ \\
\hline 16 & $\begin{array}{l}\text { The impact of feedback form on transactional distance and } \\
\text { critical thinking skills in online discussions }\end{array}$ & 2019 & $\begin{array}{l}\text { (F. G. K. Yilmaz \& } \\
\text { Yilmaz, 2019) }\end{array}$ \\
\hline 17 & $\begin{array}{l}\text { Guidance in the Design and Implementation of an Online } \\
\text { Mathematics Education Course }\end{array}$ & 2018 & (Fede, 2018) \\
\hline 18 & $\begin{array}{l}\text { E-Learning In Romanian Technical University For Mechanical } \\
\text { Engineering Students }\end{array}$ & 2019 & $\begin{array}{l}\text { Gavril, Andrei } \\
\text { Mihalache, \& Lucian, } \\
\text { 2019) }\end{array}$ \\
\hline 19 & $\begin{array}{l}\text { Teachers' roles in light of massive open online courses } \\
\text { (MOOCs): Evolution and challenges in higher distance } \\
\text { education }\end{array}$ & 2018 & $\begin{array}{l}\text { (Gil-Jaurena } \\
\text { Domínguez, 2018) }\end{array}$ \\
\hline 20 & Forum on seminary teaching and formation online & 2019 & (Gin et al., 2019) \\
\hline 21 & $\begin{array}{l}\text { GroupMe: investigating use of mobile instant messaging in } \\
\text { higher education courses }\end{array}$ & 2019 & $\begin{array}{l}\text { (Gronseth \& Hebert, } \\
\text { 2019) }\end{array}$ \\
\hline 22 & $\begin{array}{l}\text { The Relationship Between Online Students' Perceptions of the } \\
\text { Quality of Online Instruction and New Students' Intent to Persist }\end{array}$ & 2018 & (Hancock, 2018) \\
\hline 23 & $\begin{array}{l}\text { Efficient strategies for maximizing online student satisfaction: } \\
\text { Applying technologies to increase cognitive presence, social } \\
\text { Presence, and teaching Presence }\end{array}$ & 2018 & $\begin{array}{l}\text { (Holbeck \& Hartman, } \\
\text { 2018) }\end{array}$ \\
\hline 24 & $\begin{array}{l}\text { Effective principles of informal online learning design: A } \\
\text { theory-building metasynthesis of qualitative research }\end{array}$ & 2019 & (Holland, 2019) \\
\hline 25 & $\begin{array}{l}\text { Dialogue, inquiry, and encounter: Critical geographies of online } \\
\text { higher education }\end{array}$ & 2019 & $\begin{array}{l}\text { (House-Peters, Del } \\
\text { Casino Jr, \& Brooks, } \\
\text { 2019) }\end{array}$ \\
\hline 26 & $\begin{array}{l}\text { Designing e-learning environment based on student preferences: } \\
\text { conjoint analysis approach }\end{array}$ & 2019 & (Jelena \& Ana, 2019) \\
\hline 27 & $\begin{array}{l}\text { Experiences of the Namibian College of Open Learning Tutors } \\
\text { in Using Multimedia Resources in Distance Education }\end{array}$ & 2019 & (Karipi, 2019) \\
\hline 28 & $\begin{array}{l}\text { Effect of communication management on distance learners' } \\
\text { cognitive engagement in Malaysian institutions of higher } \\
\text { learning }\end{array}$ & 2018 & (Kayode, 2018) \\
\hline 29 & $\begin{array}{l}\text { The Influence of Virtual Community Participation on } \\
\text { Transactional Distance in an Online Computer Science Course }\end{array}$ & 2018 & (L. Anderson, 2018) \\
\hline 30 & $\begin{array}{l}\text { Freshman English Composition, Course Modality, Transactional } \\
\text { Distance Theory, and Student Success. }\end{array}$ & 2018 & (Lawyer, 2018) \\
\hline
\end{tabular}




\begin{tabular}{|c|c|c|c|}
\hline 31 & $\begin{array}{l}\text { Master's Students' Perceptions and Expectations of Good Tutors } \\
\text { and Advisors in Distance Education }\end{array}$ & 2019 & $\begin{array}{l}\text { (M Kara \& Can, } \\
\text { 2019) }\end{array}$ \\
\hline 32 & $\begin{array}{l}\text { Instructional design to "train the trainers": the start@ unito } \\
\text { project at the university of Turin }\end{array}$ & 2019 & $\begin{array}{l}\text { (Marchisio, Sacchet, } \\
\& \text { Salusso, 2019) }\end{array}$ \\
\hline 33 & $\begin{array}{l}\text { Identification of the optimal faculty behaviors for performance } \\
\text { improvement in distance education }\end{array}$ & 2020 & $\begin{array}{l}\text { (Mehmet Kara \& } \\
\text { Yildirim, 2020) }\end{array}$ \\
\hline 34 & Research in Distance Education: A Summary & 2019 & $\begin{array}{l}\text { (Michael Simonson, } \\
\text { 2019) }\end{array}$ \\
\hline 35 & $\begin{array}{l}\text { Analysing the predictive power for anticipating assignment } \\
\text { grades in a massive open online course }\end{array}$ & 2018 & $\begin{array}{l}\text { (Moreno-Marcos et } \\
\text { al., 2018) }\end{array}$ \\
\hline 36 & Editorial:to interact or not to interact is NOT the question! & 2018 & (Naidu, 2018) \\
\hline 37 & AECT Instructional Design Standards for Distance Learning & 2018 & (Piña, 2018) \\
\hline 38 & $\begin{array}{l}\text { Reducing transactional distance in online and blended courses } \\
\text { through the use of a closed social media platform }\end{array}$ & 2018 & $\begin{array}{l}\text { (Quong, Snider, \& } \\
\text { Early, 2018) }\end{array}$ \\
\hline 39 & $\begin{array}{l}\text { Assigned roles as a structuring tool in online discussion groups: } \\
\text { comparison of transactional distance and knowledge sharing } \\
\text { behaviors }\end{array}$ & 2019 & $\begin{array}{l}\text { (R. Yilmaz \& Yilmaz, } \\
\text { 2019) }\end{array}$ \\
\hline 40 & $\begin{array}{l}\text { Universal design for learning: Guidelines for accessible online } \\
\text { instruction }\end{array}$ & 2018 & $\begin{array}{l}\text { (Rogers-Shaw, Carr- } \\
\text { Chellman, \& Choi, } \\
\text { 2018) }\end{array}$ \\
\hline 41 & $\begin{array}{l}\text { Toward educational requirements model for Mobile learning } \\
\text { development and adoption in higher education }\end{array}$ & 2018 & $\begin{array}{l}\text { (Sarrab, Al-Shihi, Al- } \\
\text { Manthari, \& } \\
\text { Bourdoucen, 2018) }\end{array}$ \\
\hline 42 & $\begin{array}{l}\text { Undergraduate Kinesiology Students' Experiences in Online } \\
\text { Motor Development Courses }\end{array}$ & 2018 & $\begin{array}{l}\text { (Sato \& Haegele, } \\
2018)\end{array}$ \\
\hline 43 & $\begin{array}{l}\text { Distance Education: Definitions, Generations, Key Concepts and } \\
\text { Future Directions. }\end{array}$ & 2018 & (Saykili, 2018) \\
\hline 44 & Reducing distance through online international collaboration & 2020 & $\begin{array}{l}\text { (Schreiber \& Jansz, } \\
\text { 2020) }\end{array}$ \\
\hline 45 & The polarizing effect of the online flipped classroom & 2020 & $\begin{array}{l}\text { (Stöhr, Demazière, \& } \\
\text { Adawi, 2020) }\end{array}$ \\
\hline 46 & Factors determining e-learning service quality & 2018 & $\begin{array}{l}\text { (Uppal, Ali, } \quad \& \\
\text { Gulliver, 2018) }\end{array}$ \\
\hline 47 & $\begin{array}{l}\text { Online Doctoral Student Satisfaction as Influenced by } \\
\text { Personality and Transactional Distance. }\end{array}$ & 2018 & (Vaughn, 2018) \\
\hline 48 & $\begin{array}{l}\text { Perceptions of Undergraduate Students of Student-Regulated } \\
\text { Online Courses }\end{array}$ & 2018 & $\begin{array}{l}\text { (Wakeling, Doral, } \\
\text { Robertson, \& Patrono, } \\
\text { 2018) }\end{array}$ \\
\hline 49 & $\begin{array}{l}\text { Technology matters - The impact of transactional distance on } \\
\text { satisfaction in online distance learning }\end{array}$ & 2018 & $\begin{array}{l}\text { (Weidlich } \\
\text { Bastiaens, 2018) }\end{array}$ \\
\hline 50 & $\begin{array}{l}\text { Exploring the influences of MOOC design features on student } \\
\text { performance and persistence }\end{array}$ & 2019 & (Xing, 2019) \\
\hline 51 & $\begin{array}{l}\text { Learning strategies predicting the perception of social presence } \\
\text { of distance education students }\end{array}$ & 2018 & $\begin{array}{l}(\mathrm{Y} \quad \mathrm{Z} \text { Olpak } \\
\text { Çakmak, 2018) }\end{array}$ \\
\hline 52 & Student engagement in distance-based vocational education & 2020 & $\begin{array}{l}\text { (Yates, Brindley- } \\
\text { Richards, \& Thistoll, } \\
\text { 2020) }\end{array}$ \\
\hline 53 & $\begin{array}{l}\text { Sense of challenge, threat, self-efficacy, and motivation of } \\
\text { students learning in virtual and blended courses }\end{array}$ & 2019 & $\begin{array}{l}\text { (Zilka, Rahimi, \& } \\
\text { Cohen, 2019) }\end{array}$ \\
\hline 54 & $\begin{array}{l}\text { Here or there instruction: Lessons learned in implementing } \\
\text { innovative approaches to blended synchronous learning }\end{array}$ & 2019 & (Zydney et al., 2019) \\
\hline
\end{tabular}

